\section{Smith ScholarWorks}

$10-1-2013$

\section{Stratigraphic Framework, Discontinuity Surfaces, and Regional Significance of Campanian Slope to Ramp Carbonates from Central Dalmatia, Croatia}

\author{
M. Brlek \\ Croatian Geological Survey \\ T. Korbar \\ Croatian Geological Survey \\ B. Cvetko Tešović \\ University of Zagreb \\ B. Glumac \\ Smith College, bglumac@smith.edu \\ L. Fuček \\ Croatian Geological Survey
}

Follow this and additional works at: https://scholarworks.smith.edu/geo_facpubs

Part of the Geology Commons

\section{Recommended Citation}

Brlek, M.; Korbar, T.; Cvetko Tešović, B.; Glumac, B.; and Fuček, L., "Stratigraphic Framework, Discontinuity Surfaces, and Regional Significance of Campanian Slope to Ramp Carbonates from Central Dalmatia, Croatia" (2013). Geosciences: Faculty Publications, Smith College, Northampton, MA.

https://scholarworks.smith.edu/geo_facpubs/155 


\title{
Stratigraphic framework, discontinuity surfaces, and regional significance of Campanian slope to ramp carbonates from central Dalmatia, Croatia
}

\author{
M. Brlek • T. Korbar • B. Cvetko Tešović • \\ B. Glumac $\cdot$ L. Fuček
}

Received: 12 April 2012/Accepted: 15 October 2012/Published online: 8 November 2012

(C) Springer-Verlag Berlin Heidelberg 2012

\begin{abstract}
The sedimentology, microfacies, and stratigraphic age (from planktonic and benthic foraminifera and strontium-isotope stratigraphy) of a 300-m-thick Upper Cretaceous carbonate succession from the Island of Čiovo (central Dalmatia, Croatia) were analyzed in order to determine the lithostratigraphic, depositional, and chronostratigraphic framework. The Cretaceous strata were deposited in the southern part of the long-lasting (Late Triassic to Paleogene) Adriatic-Dinaridic Carbonate Platform (ADCP), one of a few late Mesozoic, intra-Tethyan, peri-Adriatic (sub)tropical archipelagos. The succession is separated by a firmground formational boundary into two lithostratigraphic units: the underlying Middle to Upper Campanian Dol Formation consisting of slope pelagic limestone with intercalated turbidites and debrites, and the overlying Upper Campanian Čiovo Formation composed of outer-ramp bioclastic-lithoclastic and echinoderm-dominated packstone. Age, lithology, and depositional settings of the Čiovo Formation are different from other penecontemporaneous, regionally important inner-platform carbonate successions within the ADCP domain. Therefore, the Čiovo Formation is proposed here as a new
\end{abstract}

M. Brlek ( $)$ · T. Korbar · L. Fuček

Department of Geology, Croatian Geological Survey,

Sachsova 2, 10000 Zagreb, Croatia

e-mail: mihovil.brlek@hgi-cgs.hr

B. Cvetko Tešović

Department of Geology, Faculty of Science, University

of Zagreb, Horvatovac 102a, 10000 Zagreb, Croatia

B. Glumac

Department of Geosciences, Smith College,

Northampton, MA 01063, USA lithostratigraphic unit. Regionally important condensed intervals in the form of at least two firmground surfaces, characterized by Thalassinoides burrows (with phosphatic mineralization) that belong to the Glossifungites ichnofacies, occur in the lowermost part of the Čiovo Formation. Abrupt shallowing of depositional environments at the boundary between the Dol and the Čiovo Formation, and the generation of the formational boundary firmground, likely correlate with the regionally recorded Upper Campanian Event that represents a global eustatic sea-level fall. A regionally important subaerial exposure surface with nodular calcrete, rhizoliths, and Microcodium aggregates in the upper part of the Čiovo Formation represents a regional subaerial unconformity that was recorded across the ADCP domain and was interpreted as a consequence of diachronous and differential uplift of various parts of the platform in response to the formation of a forebulge in front of the approaching Dinaridic orogen.

Keywords Campanian - Slope-to-ramp carbonates · Discontinuity surfaces - Adriatic-Dinaridic Carbonate Platform $\cdot$ Regional correlation

\section{Introduction}

The Island of Čiovo is located in the Adriatic Sea near the northeastern coast of central Dalmatia, Croatia (Fig. 1a, b). The island consists entirely of Upper Cretaceous carbonates and Paleogene deposits (Fig. 1c, d). Upper Cretaceous carbonate platform stratigraphy has been examined in detail on nearby Brač Island (Fig. 1c; Gušić and Jelaska 1990; Steuber et al. 2005). The reconnaissance work reported here has recognized some pronounced differences in the character of the Upper Cretaceous succession on 
Fig. 1 Location of the Island of Ćiovo (arrow) on a the paleogeographic sketch-map showing peri-Adriatic carbonate platforms and shelves (light blue) and $\mathbf{b}$ tectonic map (modified from Korbar 2009). c Portion of the Geological Map of the Republic of Croatia 1:300,000 (GKRH 2009) (marked by a rectangle in b) showing simplified geology of central Dalmatia (Croatia): green color-Upper Cretaceous carbonates (34), orange colorPaleogene carbonates (39) and clastics (40). d Geological map of the western part of the Island of Čiovo and neighboring Fumija Island (marked by a rectangle in $\mathbf{c}$ )
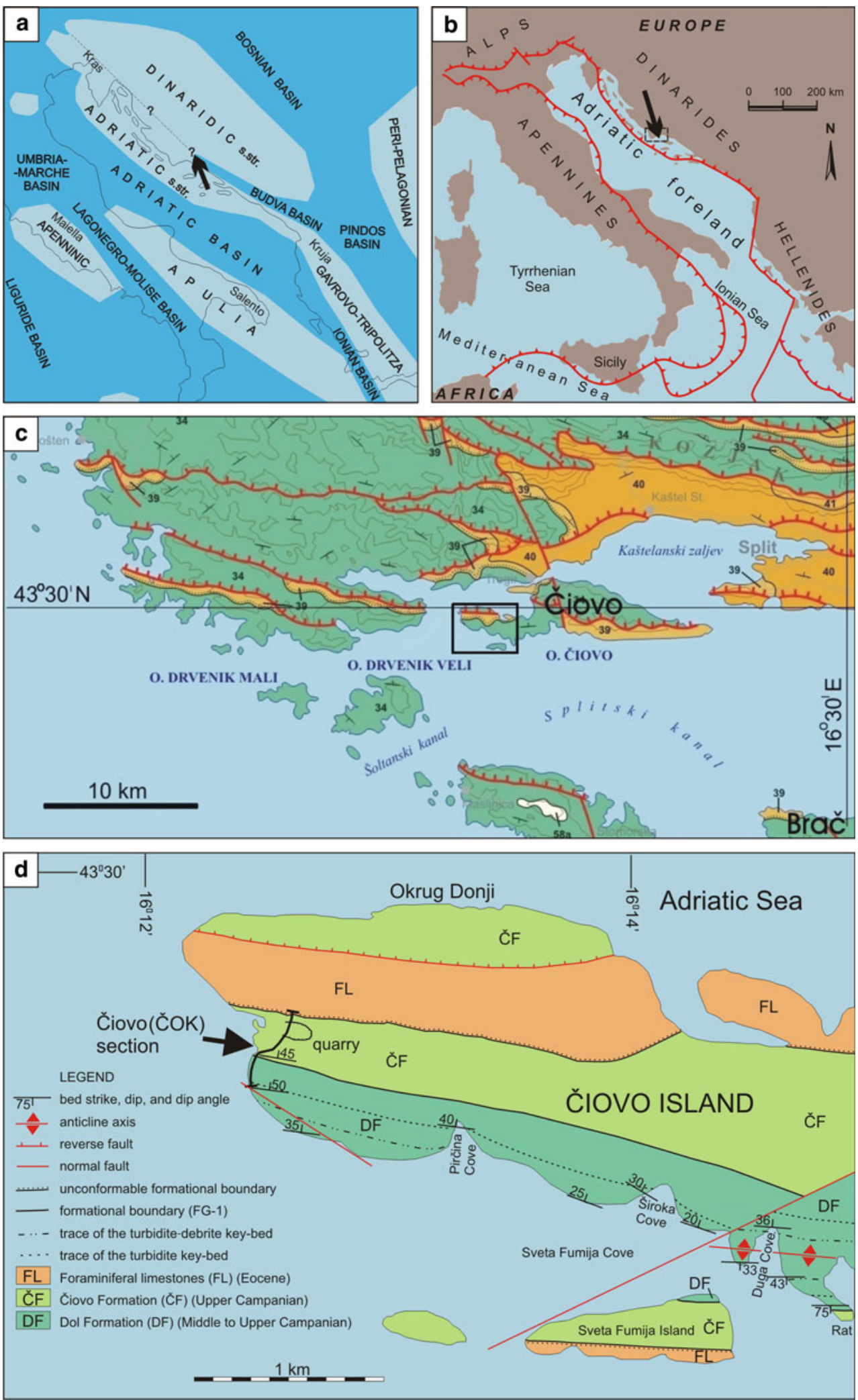

Čiovo relative to contemporaneous successions exposed elsewhere in the region, which indicates that the Ćiovo succession may provide important insights into regional
Campanian stratigraphy and sedimentology. The current study focuses on documenting these differences and discussing their significance. 
To accomplish these objectives, a relatively wellexposed 300-m-thick uppermost Upper Cretaceous carbonate succession from the southwestern part of the island (ČOK section) (Figs. 1c, d, 2) has been examined, along with geological mapping of the southwestern part of the island as well as the neighboring Sveta Fumija Island (Fig. 1d). This succession is unconformably overlain by Eocene Foraminiferal limestones (Fig. 3). This study also focused on two types of discontinuity surface, namely firmgrounds and subaerial exposure surfaces, present within the succession (Fig. 3), and their lateral extent (Fig. 1d). Such discontinuity surfaces (Sattler et al. 2005; Christ et al. 2012; Rameil et al. 2012; Schwarz and Buatois 2012) are commonly recorded in carbonate successions (Clari et al. 1995; Hillgärtner 1998) and are often useful in stratigraphic correlations and sequence stratigraphy.

Thus, the main objectives of this study were: (1) determination of the lithostratigraphy (lithology and microfacies analysis), stratigraphic age (analysis of microfossil content with special emphasis on planktonic and benthic foraminifera and strontium-isotope stratigraphy on rudist shells) and depositional settings of the Čiovo succession, as well as a comparison and correlation with other regionally important stratigraphic sections, (2) analysis, classification and lateral extent of associated discontinuity surfaces and discussion of their stratigraphic significance, and (3) evaluation of the regional importance and correlation of the Čiovo succession and recorded discontinuity surfaces in the framework of regional and global stratigraphy.

\section{Geological setting}

The Upper Cretaceous carbonates from the Island of Čiovo were deposited in the southern part of the long-lasting (Late Triassic to Paleogene) Adriatic-Dinaridic Carbonate Platform (ADCP) (sensu lato, cf. Pamić et al. 1998; Korbar 2009) (Fig. 1a, b), also named the Adriatic Carbonate Platform (AdCP) (cf. Vlahović et al. 2005). This carbonate platform was a typical central Tethyan ('peri-Adriatic' or central-northern Mediterranean) Mesozoic archipelago, characterized by a very thick succession of carbonate deposits and a rather complex platform architecture (Vlahović et al. 2005). The Upper Cretaceous stratigraphy of the south-central part of the Adriatic Carbonate Platform (ACP) (sensu stricto, cf. Jenkyns 1991; Korbar 2009) was described in detail on the neighboring Island of Brač
Fig. 2 General chronostratigraphy and lithostratigraphy for investigated strata in the centralsouthern part of the ADCP domain (modified from Kapović and Bauer 1971; Gušić and Jelaska 1990; Steuber et al. 2005). Time-scales of Obradovich (1993; 70-98.5 Ma) and Cande and Kent (1995; 70-65 Ma);

Campanian and Maastrichtian substage boundaries (dashed lines) after Gradstein et al. (1994)

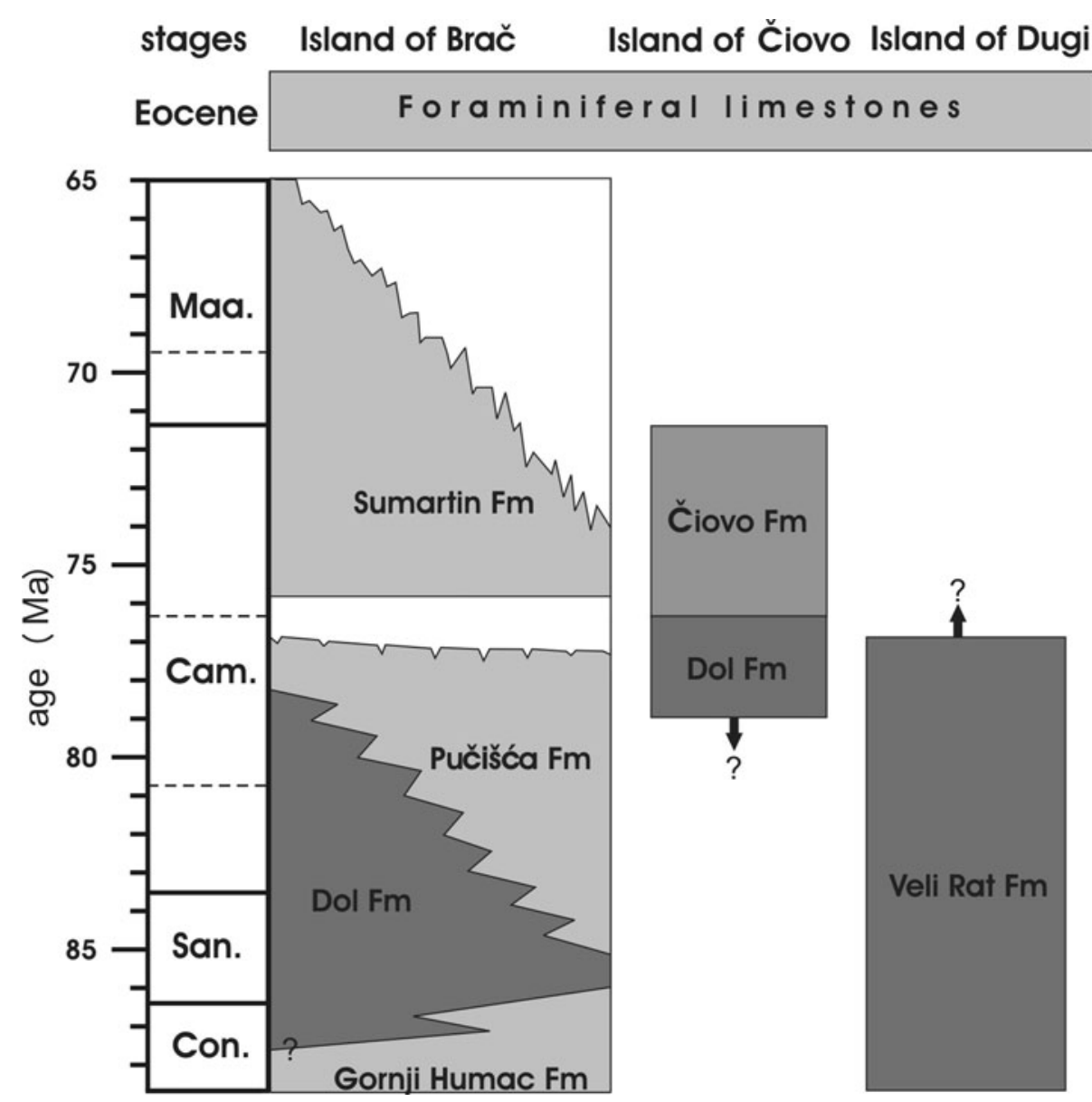




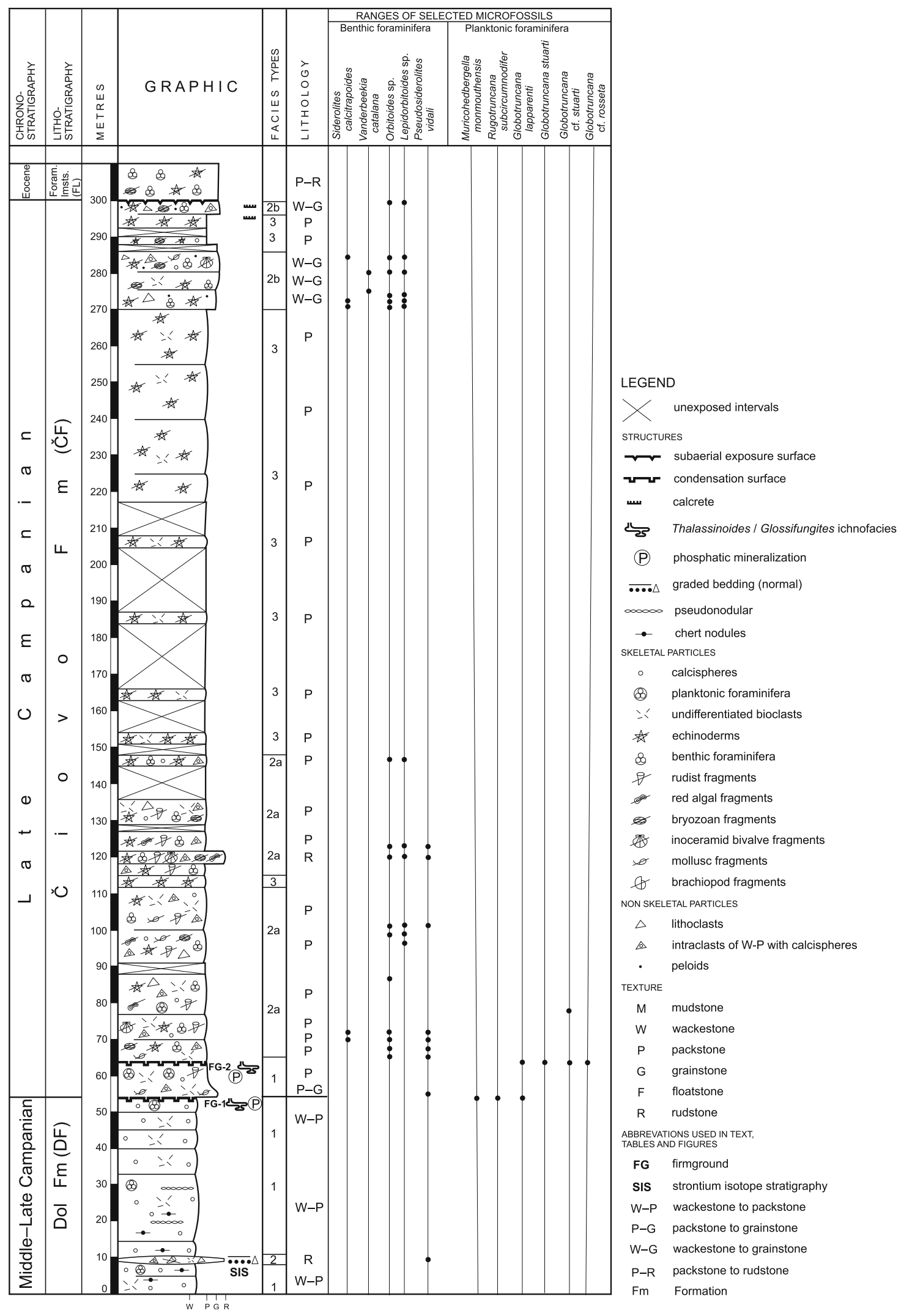

Fig. 3 Stratigraphic column of the Middle to Upper Campanian limestone succession on the Island of Čiovo with accompanying legend 
Table 1 Facies types, sedimentary structures and microfossils of the Dol and Čiovo Formations from the ČOK section and the southern part of the Island of Čiovo, as observed in the field and petrographic thin-sections

\begin{tabular}{|c|c|c|c|c|}
\hline $\begin{array}{l}\text { Facies } \\
\text { type }\end{array}$ & $\begin{array}{l}\text { Distribution } \\
\text { (m) within the ČOK } \\
\text { section (Fig. 3) }\end{array}$ & $\begin{array}{l}\text { Sedimentary structures and } \\
\text { classification }\end{array}$ & Dominant components & $\begin{array}{l}{ }^{1} \text { Planktonic and }{ }^{2} \text { benthic } \\
\text { foraminifera }\end{array}$ \\
\hline \multicolumn{5}{|c|}{ Čiovo Formation } \\
\hline 4 & 291, 294 and 299 & Calcrete & $\begin{array}{l}\text { Nodules, rhizoliths, Microcodium } \\
\text { aggregates (Fig. 9) }\end{array}$ & \\
\hline 3 & $\begin{array}{l}113-114 ; 146.5-270 \\
287-295\end{array}$ & $\begin{array}{l}\text { Monotonous, thick-bedded strata with } \\
\text { sharp lower and upper bedding } \\
\text { planes (Fig. 5a); packstone }\end{array}$ & $\begin{array}{l}\text { Echinoderms (crinoids and } \\
\text { echinoids) with syntaxial } \\
\text { overgrowths (Fig. } 5 \mathrm{~h} \text { ) }\end{array}$ & \\
\hline $2 b$ & $270-287 ; 295-299$ & $\begin{array}{l}\text { Monotonous, thick-bedded strata with } \\
\text { sharp lower and upper bedding } \\
\text { planes (Fig. 5a); dominant } \\
\text { bioclastic-lithoclastic packstone- } \\
\text { grainstone, sporadic wackestone to } \\
\text { packstone (Fig. } 5 \mathrm{~g} \text { ) }\end{array}$ & $\begin{array}{l}\text { Bioclasts of echinoderms with } \\
\text { syntaxial overgrowths, } \\
\text { bryozoans, peloids, cortoids, } \\
\text { benthic foraminifera, rudists } \\
\text { and inoceramid bivalves; } \\
\text { calcispheres in wackestone- } \\
\text { packstone matrix and } \\
\text { intraclasts (Fig. 5g) }\end{array}$ & $\begin{array}{l}{ }^{2} \text { (Fig. 3): V. catalana } \text { (Fig. 11c, } \\
\text { d), Siderolites cf. } \\
\text { calcitrapoides, Lepidorbitoides } \\
\text { sp., Orbitoides } \\
\text { sp.,Goupillaudina sp. }\end{array}$ \\
\hline $2 \mathrm{a}$ & $66.2-113 ; 114-146.5$ & $\begin{array}{l}\text { Monotonous (Fig. 5b), thick-bedded } \\
\text { strata with sharp lower and upper } \\
\text { bedding planes; packstone (rare } \\
\text { rudstone at } 119-123 \mathrm{~m} \text { ) }\end{array}$ & $\begin{array}{l}\text { Bioclasts of echinoderms } \\
\text { (crinoids and echinoids) with } \\
\text { syntaxial overgrowths, benthic } \\
\text { foraminifera, bryozoans, } \\
\text { rudists, red algae, inoceramid } \\
\text { bivalves; intraclasts of } \\
\text { wackestone-packstone with } \\
\text { calcispheres (Fig. 5b-d) } \\
\text { (locally in matrix) }\end{array}$ & $\begin{array}{l}{ }^{1} \text { (Fig. 3): Globotruncana } \mathrm{cf} . \\
\text { stuarti; } \\
{ }^{2} \text { (Fig. 3): S. calcitrapoides } \\
\text { (Fig. 11a, b), Lepidorbitoides } \\
\text { sp., P. vidali, Orbitoides sp. }\end{array}$ \\
\hline 1 & $56-66.2$ & $\begin{array}{l}\text { Sharp boundary with the underlying } \\
\text { pelagic limestone, normal } \\
\text { gradation, upper firmground } \\
(65.9-66 \mathrm{~m}) \text { (Figs. } 3,7) \text {; } \\
\text { Lower part: bioclastic-lithoclastic } \\
\text { packstone-grainstone (which also } \\
\text { fill burrows of the lower } \\
\text { firmground) grading upward into } \\
\text { packstones }\end{array}$ & $\begin{array}{l}\text { Packstone-grainstone with } \\
\text { fragments of rudists, other } \\
\text { molluscs, echinoderms, benthic } \\
\text { foraminifera, other bioclasts, } \\
\text { intraclasts of wackestone- } \\
\text { packstone with calcispheres in } \\
\text { the lower part grading upward } \\
\text { into packstone with additional } \\
\text { fragments of planktonic } \\
\text { foraminifera, and calcispheres. }\end{array}$ & $\begin{array}{l}{ }^{1} \text { (Fig. 3): Globotruncana stuarti } \\
\text { (Fig. 10c), Globotruncana } \mathrm{cf} . \\
\text { stuarti (Fig. 10d), } \\
\text { Globotruncana cf. rosseta } \\
\text { (Fig. 10e), G. lapparenti; } \\
{ }^{2} \text { P. vidali, Goupillaudina sp. }\end{array}$ \\
\hline \multicolumn{5}{|c|}{ Dol Formation } \\
\hline 2 & $\begin{array}{l}9 \text { (20-cm-thick } \\
\text { intercalation with } \\
\text { lateral thinning) }\end{array}$ & $\begin{array}{l}\text { Sharp and undulating (?erosional) } \\
\text { boundary with the underlying } \\
\text { pelagic limestones, normal } \\
\text { gradation with pronounced } \\
\text { transition into the overlying pelagic } \\
\text { limestone (Fig. } 4 \mathrm{a}, \mathrm{b} \text { ); bioclastic- } \\
\text { lithoclastic clast-supported rudstone }\end{array}$ & $\begin{array}{l}\text { Bioclasts: rudists (mainly } \\
\text { radiolitids), echinoderms, other } \\
\text { molluscs, benthic foraminifera; } \\
\text { polymict lithoclasts: packstone } \\
\text { and grainstone with bioclasts } \\
\text { and wackestone-packstone with } \\
\text { calcispheres (Fig. 4c) }\end{array}$ & ${ }^{2} P$. vidali, Goupillaudina sp. \\
\hline $2_{1}$ & $\begin{array}{l}\text { ( Lateral equivalent } \\
\text { of facies type } 2, \\
\text { Fig. 1d) (more than } \\
\text { 1-m-thick } \\
\text { intercalation) }\end{array}$ & $\begin{array}{l}\text { Sharp and undulating boundary with } \\
\text { the underlying pelagic limestone; } \\
\text { normal gradation with gradual } \\
\text { transition into the overlying pelagic } \\
\text { limestone; parallel lamination in the } \\
\text { upper parts (Fig. 4d, e); bioclastic- } \\
\text { lithoclastic clast-supported rudstone } \\
\text { and matrix-supported floatstone in } \\
\text { the basal part grading upward into } \\
\text { packstone and wackestone }\end{array}$ & $\begin{array}{l}\text { Bioclasts: rudist and other } \\
\text { bioclasts; lithoclasts: pelagic } \\
\text { wackestone-packstone with } \\
\text { calcispheres }\end{array}$ & \\
\hline
\end{tabular}


Table 1 continued

\begin{tabular}{|c|c|c|c|c|}
\hline $\begin{array}{l}\text { Facies } \\
\text { type }\end{array}$ & $\begin{array}{l}\text { Distribution } \\
\text { (m) within the ČOK } \\
\text { section (Fig. 3) }\end{array}$ & $\begin{array}{l}\text { Sedimentary structures and } \\
\text { classification }\end{array}$ & Dominant components & $\begin{array}{l}{ }^{1} \text { Planktonic and }{ }^{2} \text { benthic } \\
\text { foraminifera }\end{array}$ \\
\hline $2_{2}$ & $\begin{array}{l}\text { ( } \sim \text { Stratigraphically } \\
\text { below the ČOK } \\
\text { section, Fig. 1d) (2- } \\
\text { m-thick } \\
\text { intercalation) }\end{array}$ & $\begin{array}{l}\text { Basal part: sharp and undulating } \\
\text { boundary with the underlying } \\
\text { pelagic limestone, no gradation; } \\
\text { bioclastic-lithoclastic clast- } \\
\text { supported rudstone and matrix- } \\
\text { supported floatstone } \\
\text { Central part (the thickest): significant } \\
\text { vertical breaks in dominant grain } \\
\text { sizes and facies types, vertical } \\
\text { stacking (different facies types) of } \\
\text { lobes and channel-like structures of } \\
\text { changing lateral and vertical } \\
\text { thickness and extent, with sharp and } \\
\text { undulating lower and upper } \\
\text { boundaries (Fig. 4f, g), deformed } \\
\text { and undulating intercalations and } \\
\text { lithoclasts (decimeter-size) of } \\
\text { pelagic wackestone-packstone, no } \\
\text { gradation; bioclastic wackestone } \\
\text { and packstone, bioclastic- } \\
\text { lithoclastic matrix-supported } \\
\text { floatstone (Fig. 4f, g), pelagic } \\
\text { wackestone-packstone } \\
\text { Upper part: normal gradation with } \\
\text { gradual transition into the overlying } \\
\text { pelagic limestone, parallel } \\
\text { lamination; bioclastic-lithoclastic } \\
\text { clast-supported rudstone and } \\
\text { matrix-supported floatstone in the } \\
\text { lower part passing upward into } \\
\text { packstone and wackestone }\end{array}$ & $\begin{array}{l}\text { Bioclasts: rudists and other } \\
\text { bioclasts, lithoclasts: pelagic } \\
\text { wackestone-packstone with } \\
\text { calcispheres }\end{array}$ & \\
\hline 1 & $0-56$ & $\begin{array}{l}\text { Medium- to thick-bedded, locally } \\
\text { massive or of pseudonodular } \\
\text { appearance, chert nodules (Figs. 3, } \\
\text { 4h), lower firmground (FG-1) } \\
\text { (55.5-56 m) (Figs. 3, 6); } \\
\text { wackestone-packstone }\end{array}$ & $\begin{array}{l}\text { Calcispheres, planktonic } \\
\text { foraminifera, other bioclasts } \\
\text { (Fig. } 4 \text { i) }\end{array}$ & $\begin{array}{l}{ }^{1} \text { (Fig. 3): Muricohedbergella } \mathrm{cf} . \\
\text { monmouthensis (Fig. 10a), } \\
\text { Globotruncana mariei, } R . \\
\text { subcircumnodifer (Fig. 10b), G. } \\
\text { lapparenti; }{ }^{2}: \text { Navarella } \\
\text { joaquini }\end{array}$ \\
\hline
\end{tabular}

Facies types 2 and $2_{1}$ of the Dol Formation are interpreted as calciturbidites, while facies type $2_{2}$ is interpreted as turbidite and/or debrite (for lateral correlation of these deposits, see Fig. 1d and Results section). Depositional setting of the Dol Formation is determined as a slope, while that of the Čiovo Formation represents an outer ramp

(Gušić and Jelaska 1990; Cvetko Tešović et al. 2001; Moro et al. 2002; Steuber et al. 2005). Carbonate deposits from Brač were subdivided into several informal lithostratigraphic units, including the Gornji Humac Formation (Turonian to Coniacian), the Dol Formation (Coniacian to Campanian intra-platform deeper-water carbonates, the second Late Cretaceous pelagic episode), the Pučišća Formation (Santonian to Campanian), and the Sumartin Formation (Upper Campanian to Maastrichtian/?Paleocene) (Fig. 2).

On the Islands of Brač (Gušić and Jelaska 1990) and Hvar (Korbar et al. 2010), the Lower to Middle Campanian Pučišća Formation, which is referred to as biozone CsB5 of
Fleury (1980), is unconformably overlain by the Sumartin Formation above a regional subaerial exposure surface that can be correlated to a global event of eustatic sea-level fall (see Steuber et al. 2005 and references therein). The Sumartin Formation is represented by platform-interior carbonate deposits whose Late Campanian to Mastrichtian stratigraphic range is based on the correlation of strontium isotope data with documented benthic foraminifera, namely Murciella cuvillieri Fourcade, Rhapydionina liburnica Stache (see also Vicedo et al. 2011) and Laffiteina mengaudi Astre (biozones CsB6 and CsB7 cf. Fleury 1980, recalibrated by Steuber et al. 2005). The Cretaceous to Paleogene $(\mathrm{K}-\mathrm{Pg})$ hiatus is a consequence of differential 
uplift of various parts of the platform(s), interpreted as diachronous forebulging in front of the approaching Dinaridic orogen (Otoničar 2007; Korbar 2009). However, the $\mathrm{K}-\mathrm{Pg}$ hiatus is also recorded elsewhere in the Adriatic region (Bosellini et al. 1999), and therefore cannot only be related to the forebulge effect. Lower to Middle Eocene Foraminiferal limestones unconformably overlie the Sumartin Formation (Gušić and Jelaska 1990; Marjanac et al. 1998) over a regional subaerial unconformity (Korbar 2009), and were deposited on a developing carbonate ramp (Ćosović et al. 2004) in the most distal parts of the foreland basin.

Isolated outcrops of Upper Cretaceous to Paleocene deeper-water carbonates and calcidebrites have been recorded along the NE Adriatic coast of Croatia in central and southern Dalmatia (see Korbar 2009), including the Tilovica locality on Mosor Mt. (Ćosović et al. 2006). As proposed by Chrowicz (1975), basinal limestones in the area between the Croatian cities of Split and Dubrovnik were deposited within a trough that paleogeographically represented a NW embayment of the Budva-Cukali Basin, referred to by Korbar (2009) as the NE Adriatic trough (NEAT). In addition, Turonian to Campanian slope carbonates have also been recorded from the Dugi Otok and Premuda islands in Croatia (ADCP domain), and are generally (based on incomplete borehole data) overlain by Eocene Foraminiferal limestones (Kapović and Bauer 1971).

The stratigraphy of the ADCP and the orogenic evolution of the External Dinarides are closely related, and the subject of an ongoing debate concerning the Mesozoic paleogeography of the region (Korbar 2009). In that context, the Upper Cretaceous to Paleogene succession on Čiovo examined here may have a substantial paleogeographic significance because of its unique location close to the northwesternmost outcrops of intra/inter-platform(s) basinal deposits of the Budva Basin (Chrowicz 1975; Korbar 2009; Fig 1a).

\section{Materials and methods}

Samples intended for microfacies and microfossil analyses were collected from a 300-m-thick Upper Cretaceous ČOK section from southwestern Čiovo (Fig. 1c, d). There are several unexposed intervals in the middle part of the section (Fig. 3). Microfacies characteristics were analyzed from petrographic thin-sections according to Flügel (2004), and classified according to Dunham (1962) and Embry and Klovan (1971). The microfossil content of these thin-sections was investigated in order to determine the stratigraphic age of the units, with special emphasis on planktonic and benthic foraminifera. Identification of planktonic foraminifera and determination of planktonic foraminiferal zones followed Premoli Silva and Verga (2004). Additionally, samples intended for microfossil analysis of Paleogene Foraminiferal limestones, which overlie the Upper Cretaceous ČOK section (Fig. 3), were also collected in order to determine its stratigraphic age, with special emphasis on benthic foraminifera.

Recognition of two types of discontinuity surface present in the succession, namely firmgrounds and subaerial exposure surfaces with calcrete, was mainly based on criteria given by Bromley (1975), Wright (1994), Clari et al. (1995), and Hillgärtner (1998). Trace fossils associated with the firmgrounds were analyzed in the field, in polished hand-specimens (cut in various orientations), and in thinsection. Phosphatic mineralization of the firmgrounds was also analyzed in polished slabs and petrographic thin-sections. This was supported by complementary investigation under scanning electron microscope (SEM) using backscattered electron imaging (BSE) and energy dispersive $\mathrm{X}$-ray analysis (EDX). This semi-quantitative X-ray mapping of $\mathrm{P}, \mathrm{F}$ and $\mathrm{Ca}$ was performed using a FEI Quanta 450 SEM with EDAX TEAM EDS at the Department of Geosciences, Smith College (Northampton, Massachusetts, USA).

\section{Results}

Lithology, microfacies, and lithostratigraphy

The measured Upper Cretaceous ČOK succession is divided by a lower firmground (formational boundary, FG-1, Figs. 1d, 3) into two lithostratigraphic units: the underlying Dol Formation (DF) $(0-56 \mathrm{~m})$ and the overlying Čiovo Formation ( $\breve{C} F)(56-300 \mathrm{~m})$, and it is unconformably overlain by Eocene Foraminiferal limestones (Fig. 3). The Dol Formation is subdivided into two facies types (facies types 1 and 2) characterized by different sedimentary structures and textures, microfacies and fossil associations (Table 1; Fig. 3).

Facies type 1 is medium to thickly bedded, but locally massive or pseudonodular (Figs. 3, 4h, i). It is represented by wackestone-packstone with common calcispheres, as well as whole and fragmented planktonic foraminifera (Table 1; Fig. 3). Thalassinoides burrows with phosphatized walls were recorded in the uppermost $50 \mathrm{~cm}$ of the Dol Formation, and they are also associated with the lower firmground (FG-1) (Fig. 3). Chert nodules of centimeter to decimeter size, which are locally connected to form sheets, also occur (Figs. 3, 4h). Facies type 2 occurs at $9 \mathrm{~m}$ above the base of the ČOK section as an up to 20-cm-thick intercalation, with lateral thinning and sharp and undulating (?erosional) lower boundary with the underlying 

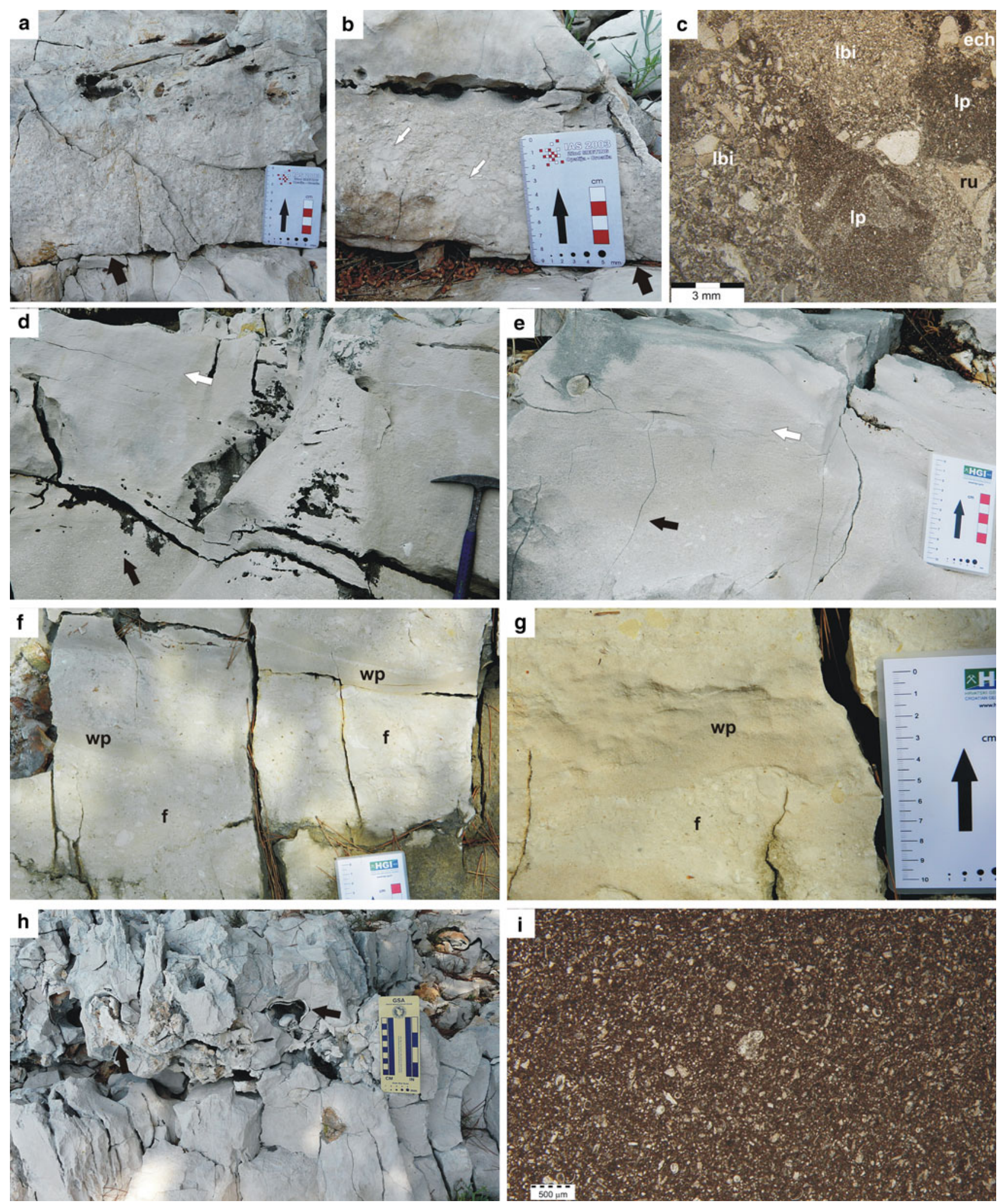

pelagic wackestone-packstone (Table 1; Fig. 4a, b). This intercalation is represented by normally graded bio-lithoclastic (more abundant lithoclasts in the lower part) clastsupported rudstone (rarely matrix-supported floatstone), that shows gradual but a pronounced transition into the overlying pelagic wackestone-packstone (Fig. 4a, b). Two types of deposit, which are genetically connected with facies type 2 of the Dol Formation in the ČOK section 
4 Fig. 4 Lithofacies types of the Dol Formation from the ČOK section $(\mathbf{a}, \mathbf{b}, \mathbf{c}, \mathbf{h}, \mathbf{i})$ and its lateral equivalents $(\mathbf{d}, \mathbf{e}, \mathbf{f}, \mathbf{g})$. a, b Field exposure of a vertical section of normally graded bioclastic-lithoclastic (white arrows) clast-supported rudstone (facies type 2) with lateral thinning and a sharp and undulating (?erosional) boundary with the underlying pelagic wackestone-packstone (black arrows in a and b), and with a gradual but pronounced transition into the overlying wackestonepackstone (especially visible in b). $\mathbf{c}$ Photomicrograph of facies type 2 represented by bioclastic-lithoclastic rudstone with larger bioclasts made mostly of rudists $(r u)$, and rarely of echinoderms (ech). Lithoclasts are very common and consist of wackestone-packstone with pelagic microfossils (mostly calcispheres) $(l p)$ as well as packstone composed of rudist and echinoderm bioclasts (lbi). d, e More than 1-m (d) and about 0.8-m- thick (e) intercalations (facies type $2_{2}$ ) of normally graded bioclastic-lithoclastic clast-supported rudstone and matrix-supported floatstone in the lower part (black arrows), that gradually transition upwards into packstone and wackestone with parallel horizontal lamination (white arrows) into the overlying pelagic wackestone-packstone (upper part of the photograph). These deposits are intercalated within pelagic wackestone-packstone strata (facies type 1), and are highlighted in Fig. 1d, together with the facies type 2, as the turbidite key-bed. Hammer in d is $32 \mathrm{~cm}$ long. f, $\mathbf{g}$ Field photographs of the central part of more than 2-m-thick laterally continuous intercalation of facies type $2_{2}$ within pelagic wackestone-packstone characterized by significant vertical breaks in dominant grain-sizes and facies types, with sharp boundaries and no observed grading. Vertical stacking of lobes and channel-like structures of changing lateral thickness and extent, with sharp and undulating lower and upper boundaries, of bioclastic wackestone and packstone ( $w p$ ) which show no signs of gradation, and bioclastic-lithoclastic mostly matrix-supported floatstone $(f)$, are visible. All of these facies types have variable lateral extent and show lateral thickening, thinning, and some local complete disappearance. These deposits are highlighted in Fig. 1d, together with the bed of uncertain stratigraphic continuity below the ČOK section, as the turbidite and/or debrite key-bed. h Field photograph of pelagic strata (facies type 1) with chert nodules (black arrows). i Photomicrograph of facies type 1 represented by wackestone-packstone with pelagic microfossils such as calcispheres and planktonic foraminifera (centre of the photomicrograph), as well as other bioclasts

(Table 1; Figs. 1d, 4), were recorded laterally during detailed geological mapping. The first type (facies type $2_{1}$ ) reaching more than $1 \mathrm{~m}$ in thickness (Table 1; Fig. 4d, e), is a lateral stratigraphic equivalent of facies type 2 in the ČOK section (i.e., a turbidite key-bed on Fig. 1d). The second type (facies type $2_{2}$ ) reaches more than $2 \mathrm{~m}$ in thickness (Table 1; Fig. 4f, g) and is laterally correlative with a 2-m-thick deposit recorded below the ČOK section (i.e., turbidite-debrite key-bed in Fig. 1d).

The Čiovo Formation is represented by monotonous, thick-bedded strata with sharp lower and upper bedding planes (Table 1; Fig. 5a) that show no signs of erosional sedimentary structures. Internal structure of individual beds is markedly monotonous and without any signs of gradation, lamination, stratification, or preferential orientation of bioand lithoclasts, although rarely beds may have areas with coarser-grained bioclasts. The Čiovo Formation is composed of five facies types (facies types 1, 2a and b, 3 and 4) characterized by different microfacies and fossil associations (Table 1; Figs. 3, 5), but it is mainly represented by bioclastic-lithoclastic packstone (facies types 1, 2a and b), and echinoderm packstone (facies type 3 ), as well as calcrete and Microcodium aggregates (facies type 4 recorded within facies $2 \mathrm{~b}$ and 3 ; Table 1; Fig. 3). Thalassinoides trace fossils occur between 65.9 and $66 \mathrm{~m}$ stratigraphically, associated with the upper firmground (FG-2) (Fig. 3).

\section{Discontinuity surfaces}

\section{Firmgrounds}

Two firmgrounds (FG-1 and FG-2) were recorded in the ČOK succession (Table 1; Fig. 3), with an additional firmground(s) present laterally in the Čiovo Formation above FG-2. The lower firmground (FG-1) marks the boundary between the Dol Formation and the Čiovo Formation $(55.5-56 \mathrm{~m})$ (formational boundary), whereas the upper firmground (FG-2) is present within facies type 1 of the Čiovo Formation $(65.9-66 \mathrm{~m})$. Lateral extent of both firmgrounds is greater than $3 \mathrm{~km}$ (Fig. 1d).

The lower firmground (FG-1), with an irregular bedding plane, is characterized by vertical to sub-vertical simple and branching Thalassinoides burrows of irregular size and shape, with sharp walls, but without pellets or bioglyphs in the burrow walls (unlined) (Fig. 6). The burrows descend to $50 \mathrm{~cm}$ below the firmground surface into the bioclastic wackestone-packstone of facies type 1 of the Dol Formation. Burrow shape ranges from simple oval and elliptical, simple tubular/cylindrical to mostly branching (Fig. 6a-e), with characteristic Y-shaped branches (Fig. 6d), with a diameter of $0.3-3 \mathrm{~cm}$. The burrows are passively filled with bioclastic-lithoclastic packstone-grainstone of facies type 1 of the Čiovo Formation (Fig. 6f, g). Burrow walls are commonly lined with phosphatic mineralization (Fig. $6 \mathrm{~g}$ ), with maximum phosphatic crust thickness of $1 \mathrm{~mm}$. Phosphatized areas (Fig. 8a, b) appear as homogenous masses with incorporated carbonate particles. An association of crudely laminated phosphatic crusts and opaque (likely iron-rich) minerals, with a maximum thickness of $1 \mathrm{~mm}$, was also observed. Under the polarizing microscope phosphates appear yellowish to brownish, and are isotropic or show a dark grey interference color under crossed polars.

The upper firmground (FG-2) is characterized by horizontal, vertical to sub-vertical, branching Thalassinoides burrow systems (Fig. 7a-f), which are also irregular in size and shape, and reach to about $10 \mathrm{~cm}$ below the surface. Horizontal branching burrow systems were observed along the upper bedding plane (Fig. 7a-c), and vertical, subvertical and branching burrows in vertical sections (Fig. 7d, e). The burrows are about $0.5-6 \mathrm{~cm}$ wide (some perhaps even wider, Fig. $7 \mathrm{a}, \mathrm{c}$ ), and are sharp-walled, without pellets or bioglyphs in the unlined burrow walls. The burrows are filled with bioclastic wackestone- 

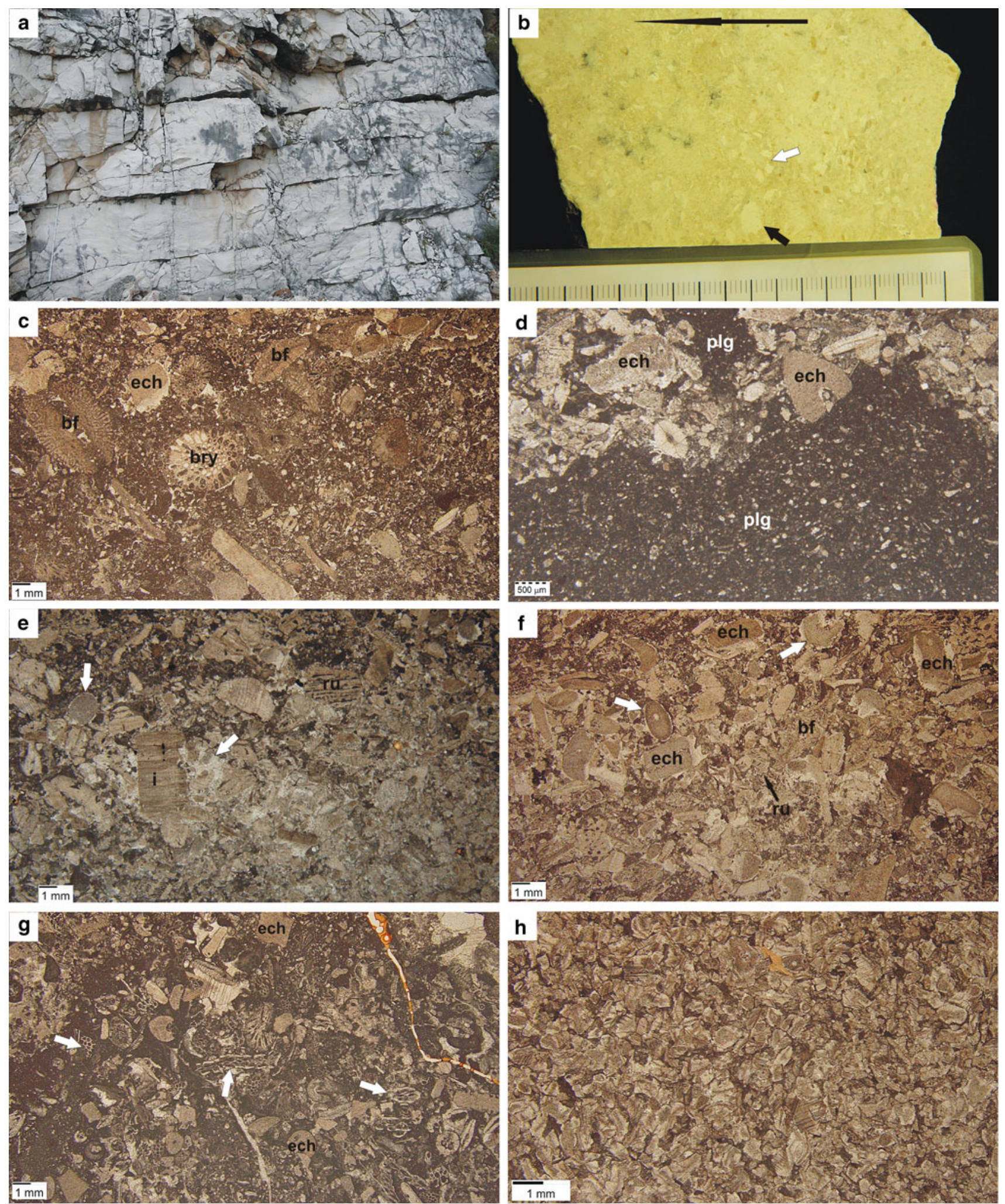

packstone different from the overlying and surrounding bioclastic packstone of facies type 1 of the Čiovo Formation (Fig. 7f). Burrow fills are also in places characterized by higher relative amounts of whole and fragmented planktonic foraminifera and calcispheres (Fig. 7f). Burrow fills and walls are commonly mineralized with phosphates (Fig. 8c-e), and in some cases glauconitized. Phosphatized areas also have elevated fluorine (F) contents (Fig. 8c-e). 
4 Fig. 5 Outer ramp deposits of the Čiovo Formation. a Field photograph of thick-bedded strata with sharp lower and upper bedding planes showing no signs of sedimentary structures that would indicate erosion. Internal structure of individual beds is markedly monotonous and without any signs of gradation, lamination, stratification, or preferential orientation of bioclasts and lithoclasts. Measuring stick for scale is $1.4 \mathrm{~m}$ long. b Polished slab of facies type $2 \mathrm{a}$ represented by bioclastic-lithoclastic packstone without any obvious sedimentary structures or orientation of bioclasts (but with some possible bioturbation), and with visible benthic foraminifera (right side and centre of photograph, white arrow), other bioclasts as well as lithoclasts of pelagic wackestone-packstone (short black arrow). Long black arrow marks the orientation of the specimen. $\mathbf{c}$ Photomicrograph of facies type 2 a represented by bioclastic packstone with benthic foraminifera (bf), bryozoans (bry), echinoderms (ech) with syntaxial overgrowths, calcispheres and other bioclasts. d Photomicrograph of facies type $2 \mathrm{a}$ with intraclasts of wackestone-packstone with calcispheres $(p l g)$ in the surrounding bioclastic packstones with echinoderm (ech) and rudist fragments. e Photomicrograph of facies type 2a represented by bioclastic packstone with echinoderm, rudist $(r u)$ and inoceramid bivalve $(i)$ bioclasts. Echinoderm fragments with syntaxial overgrowths are indicated by white arrows. f Facies type 2a represented by bioclastic packstone in which echinoderm bioclasts (ech) (crinoid lunate arm plates and circular stems, white arrows) with syntaxial overgrowths represent the dominant components. Other recognizable bioclasts belong to rudists $(r u)$ and benthic foraminifera $(b f)$. g Facies type $2 \mathrm{~b}$ consisting of bioclastic wackestone-packstone with fragments of bryozoans (white arrows), echinoderms (ech), benthic foraminifera, calcispheres and other bioclasts. h Facies type 3 represented by echinoderm packstone. This facies type is made almost entirely of echinoderm bioclasts with syntaxial overgrowths in matrix

Homogenous masses of phosphate are present in the more mineralized parts, where the primary structure is commonly partially obscured. In less mineralized parts, the primary structure remains visible (Fig. 7f). Under the polarizing microscope phosphatic crusts and more phosphatized parts of burrow fills appear yellowish, whereas the less mineralized areas appear brown. Fragments of thickshelled radiolitid rudists (up to $2 \mathrm{~cm}$ long) were also recorded in the upper firmground horizon. On the upper bedding planes of both firmgrounds (FG-1and FG-2), features that resemble boring trace fossils were observed in the field, but this could not be confirmed with hand-specimen or thin-section. Typical features associated with emergence and subaerial exposure (e.g., see Di Stefano and Mindszenty 2000; Rameil et al. 2012) were not recognized.

An additional firmground surface(s) with Thalassinoides burrows (Fig. 7g, h) was documented during geological mapping of the area (Fig. 1d). Located stratigraphically above the upper firmground (FG-2), this surface might also be present within the lowermost covered interval of the ČOK section (Fig. 3).

\section{Calcrete and Microcodium aggregates}

Calcrete (facies type 4) was observed in the field as irregular brownish and reddish patches within marine limestones at 291, 294 and $299 \mathrm{~m}$ in facies types $2 \mathrm{~b}$ and 3 of the Čiovo Formation (Table 1, Figs. 3, 9a, b). Calcrete nodules/peloids and rare pisoids of various size and shape (often well rounded) are mostly made of dark reddish micrite with few carbonate fragments (Fig. 9c-e), but they commonly include whole and fragmented typical Microcodium aggregates and multilayered calcified root cells. In addition, some parts of a calcrete are more massive, composed of homogenous dark reddish micrite. Nodules are separated by spar-filled cavities of irregular size and shape (Fig. 9d, e), and are also surrounded by dark grey micrite, and some circumgranular cracks. Spar-filled cavities with evidence for biogenic activity were also commonly observed. These biogenic features include rhizoliths in the form of root tubules and crude concentric micritic coatings of sparite-filled voids, and calcified root cells and/or Microcodium type b (sensu Alonso-Zarza et al. 1998) aggregates composed of multiple layers of isodiametric and elongated brownish calcite crystals (Fig. 9d, e), with common isolated calcite crystals. Alveolar-septal structures growing into pore space and possibly lining cavity walls (forming root tubules) were also observed (Fig. 9f). These biogenic features are commonly found together and indicate the location of a former root (Fig. 9e).

Typical Microcodium structures (sensu Košir 2004) (Fig. 9g, h) composed of single layers of elongated calcite prisms, including cylindrical, spheroidal (Fig. 9g), and laminar morphotypes (Fig. 9h), were also observed. They occur in situ and are associated with multilayered calcified root cells composed of isodiametric and elongated calcite crystals (Fig. 9g). The lateral extent of the subaerial exposure surface with calcrete occurring within the Čiovo Formation is greater than $3 \mathrm{~km}$ (Fig. 1d).

\section{Age determination}

Age determination of the Dol Formation is based on planktonic foraminifera and strontium-isotope stratigraphy, while interpretations of the Čiovo Formation utilize both planktonic and larger benthic foraminifera. Age determination of the overlying Foraminiferal limestones is based exclusively on benthic foraminifera.

\section{Planktonic foraminifera}

Planktonic foraminifera recorded at a height of $56 \mathrm{~m}$ in the Dol section (facies type 1) (Table 1; Fig. 3) include Muricohedbergella monmouthensis Olsson (Fig. 10a), Globotruncana lapparenti Brotzen, and Rugotruncana subcircumnodifer Gandolfi (Fig. 10b). This association indicates a stratigraphic range from at least the Late Campanian Radotruncana calcarata through the Early Maastrichtian Gansserina gansseri planktonic foraminiferal zones (Premoli Silva and Verga 2004). 

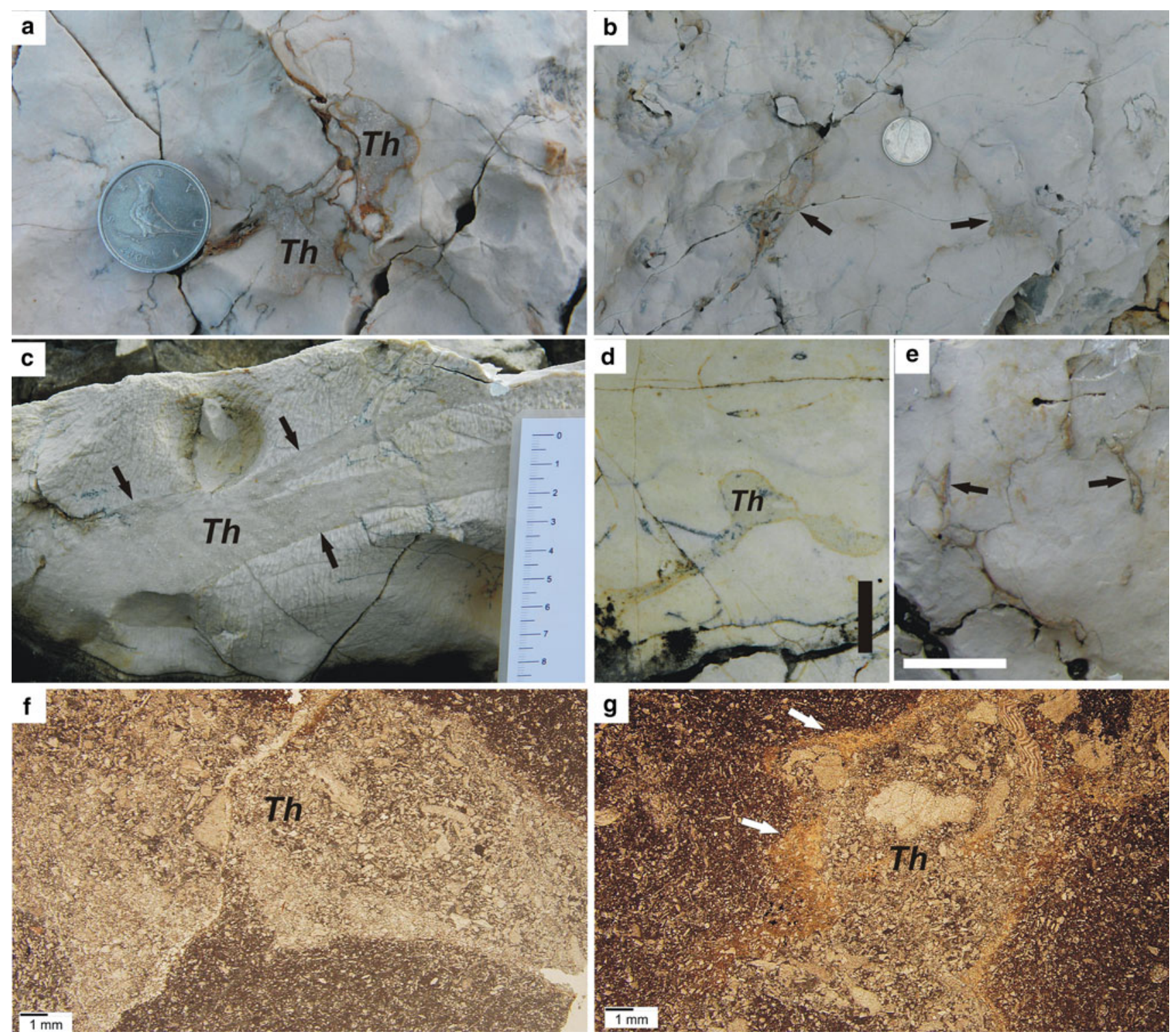

Fig. 6 Characteristics of the lower firmground (FG-1) recorded in the ČOK section $(\mathbf{a}, \mathbf{b}, \mathbf{e}, \mathbf{f}, \mathbf{g})$ and elsewhere laterally $(\mathbf{c}, \mathbf{d})$. a-e Field exposure of a vertical section of the lower firmground (FG-1, formational boundary between the Dol and Čiovo Fms; Fig. 3), with sharp walled, unlined and phosphatized, mostly branching Thalassinoides (Th, black arrows) burrows (typical Y-shaped in d) of irregular size and shape filled with packstone-grainstone of facies

Planktonic foraminifera documented from 65.9 to $66 \mathrm{~m}$ in the Čiovo section (facies type 1; Table 1; Fig. 3) are Globotruncanita stuarti de Lapparent (Fig. 10c), Globotruncanita cf. stuarti de Lapparent (also recorded at $80 \mathrm{~m}$ ) (Fig. 10d) and Globotruncana cf. rosseta Carsey (Fig. 10e). This association indicates a stratigraphic range from at least the Late Campanian $R$. calcarata through the Late Maastrichtian Abathomphalus mayaroensis planktonic foraminiferal zones (Premoli Silva and Verga 2004).

type 1 of the overlying Čiovo Formation. Coin diameter in $\mathbf{a}$ and $\mathbf{b}$ is 2.2 and $2.4 \mathrm{~cm}$, respectively. Scales in $\mathbf{d}$ and $\mathbf{e}$ are 2 and $5.6 \mathrm{~cm}$ long, respectively. f, $\mathbf{g}$ Photomicrograph showing Thalassinoides burrows $(T h)$ infilled with bioclastic-lithoclastic packstone-grainstone of facies type 1 of the Čiovo Formation. Sharp burrow walls in $\mathbf{g}$ are phosphatized (white arrows). Surrounding bioclastic wackestonespackstone belong to facies type 1 of the Dol Formation

\section{Benthic foraminifera}

Two biostratigraphically important larger benthic foraminifera were observed in the Čiovo Formation (Table 1; Fig. 3). These are Siderolites calcitrapoides Lamarck from the base of facies unit 2a (Fig. 11a, b) and possibly in facies unit 2b (Fig. 3), and Vanderbeekia catalana Hottinger and Caus (L. Hottinger personal communication) (Fig. 11c, d), from two horizons in facies unit $2 b$ 

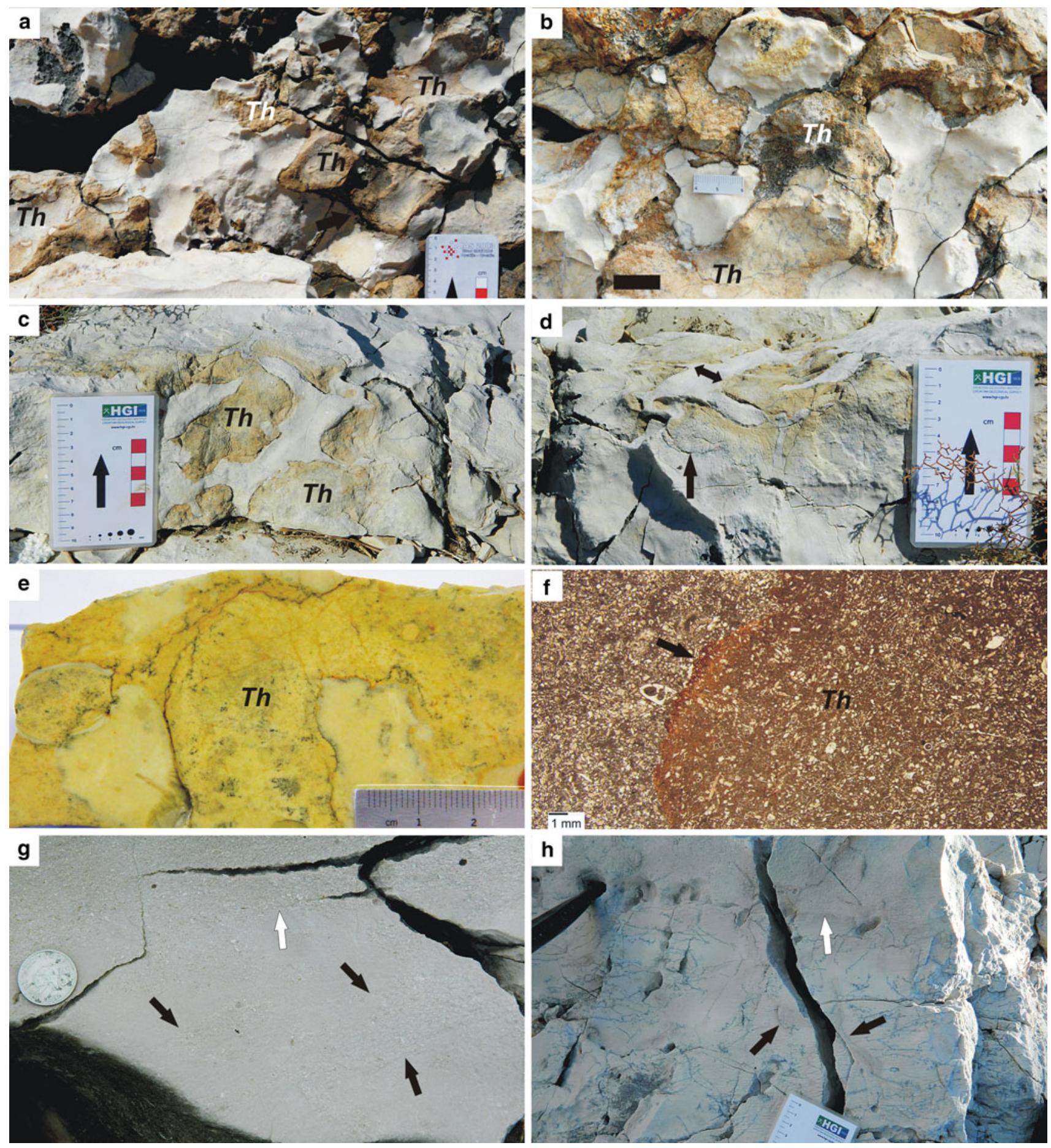

Fig. 7 Characteristics of the upper firmground (FG-2) (a-f) and an additional firmground $(\mathbf{g}, \mathbf{h})$ located stratigraphically above the FG-2. ČOK section $(\mathbf{a}, \mathbf{b}, \mathbf{e}, \mathbf{f})$ and lateral development $(\mathbf{c}, \mathbf{d}, \mathbf{g}, \mathbf{h})$. a-d Bedding plane view $(\mathbf{a}-\mathbf{c})$ and a vertical section $(\mathbf{d})$ of the upper firmground (FG-2) flocated within facies unit 1 of the Ćiovo Formation (see Fig. 3). The firmground is characterized by horizontal $(\mathbf{a}-\mathbf{c})$, vertical and subvertical (d) sharp-walled and unlined Thalassinoides burrow systems (Th, black arrows) of irregular size and shape, with downward penetration of burrows to about $10 \mathrm{~cm}(\mathbf{d})$. Scale in $\mathbf{b}$ is $2 \mathrm{~cm}$ long. e Polished slab of a vertical section with branching Thalassinoides burrows (Th) with sharp and unlined walls.

f Photomicrographs of burrows (Th) showing sharp contact between bioclastic wackestone-packstone, which represents burrow fills, and the surrounding bioclastic packstone of facies type 1 of the Čiovo Formation (black arrow). Burrow walls in $\mathbf{f}$ are mineralized (partly phosphatized), and burrow fills are characterized by a higher relative amount of planktonic foraminifera and calcispheres. $\mathbf{g}$, h Firmground located above the upper firmground (FG-2). Both $\mathbf{g}$ and $\mathbf{h}$ show the contact (white arrows) between the underlying finer-grained bioclastic packstone with sharp-walled and unlined Thalassinoides burrows (black arrows) and the overlying coarser-grained bioclastic packstone that fills the Thalassinoides burrows. Diameter of coin in $\mathbf{g}$ is $2.5 \mathrm{~cm}$ 

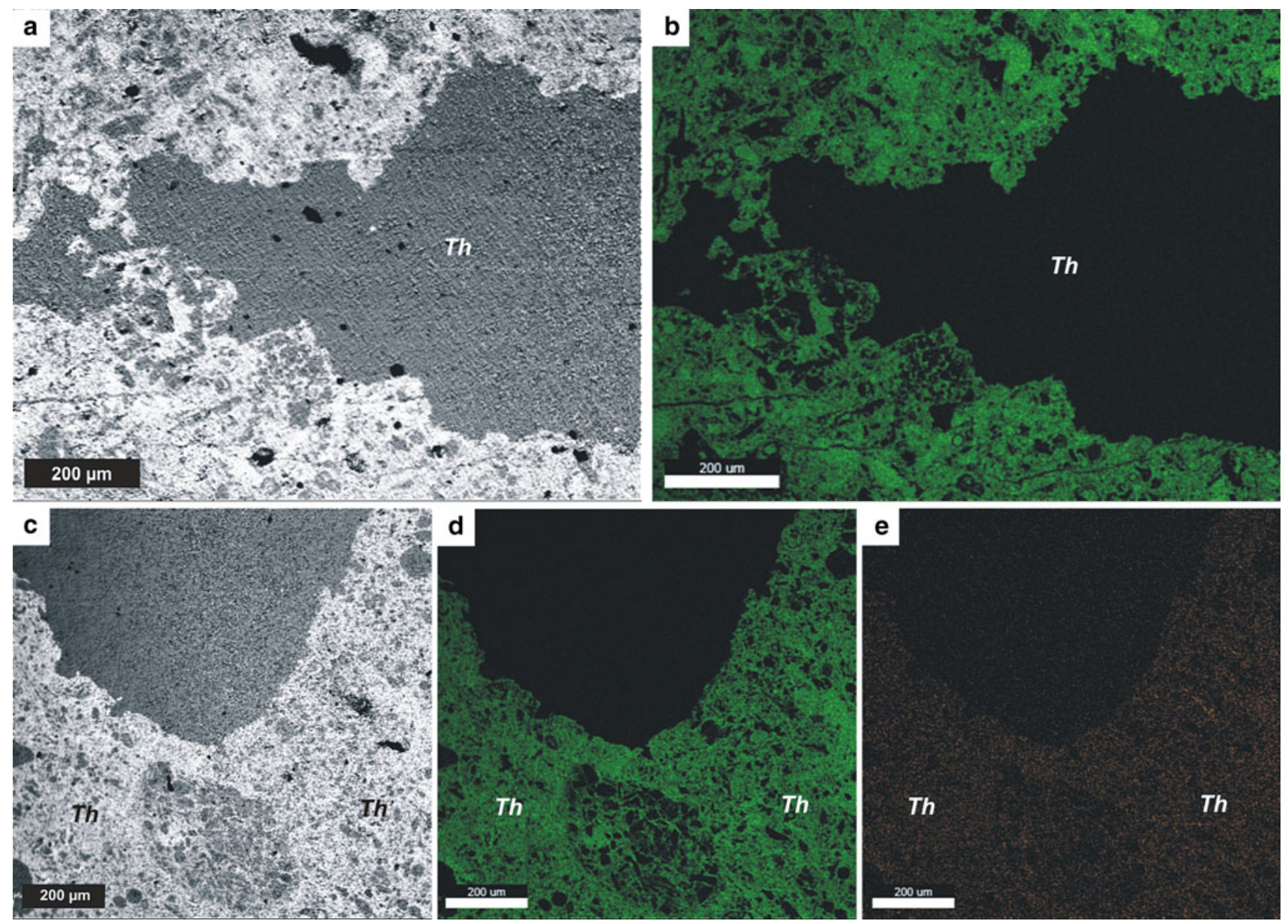

Fig. 8 Phosphatic crusts on burrow $(T h)$ walls of the lower firmground (FG-1) (a, b) and phosphatized burrow (Th) fills of the upper firmground (FG-2) (c-e) from the ČK section (Fig. 3). BSE images $(\mathbf{a}, \mathbf{c})$ and elemental maps for phosphorus $(\mathbf{b}, \mathbf{d})$ and fluorine

(Fig. 3). The stratigraphic range of S. calcitrapoides can be correlated with the latest Late Campanian/earliest Early Maastrichtian G. gansseri to the Late Maastrichtian A. mayaroensis planktonic foraminiferal zones in the Tethyan area (Billotte in Hardenbol et al. 1998), or with the Late Campanian Globotruncana aegyptiaca to Late Maastrichtian A. mayaroensis planktonic foraminiferal zones in the Anatolian basins of Turkey (Özkan-Altiner and Özcan 1999). According to Hottinger and Caus (2007), who first described $V$. catalana in the Lower Areny Sandstone Formation from Spain (Caus and Gómez-Garrido 1989), this foraminifera has an age span from the late Middle Campanian to Late Campanian. Lepidorbitoides sp., Orbitoides sp., Pseudosiderolites vidali Douvillé and other un-identified foraminifera are also present in the Čiovo Formation (Fig. 3). Benthic foraminifera recorded in the Foraminiferal limestones, which unconformably overlie the Upper Campanian limestones of the Čiovo Formation (Fig. 3), belong to the Early Eocene. (e). White areas in a and $\mathbf{c}$ correspond to phosphate, while grey areas correspond to carbonates. Bright areas in $\mathbf{b}$ and $\mathbf{d}$ correspond to high $\mathrm{P}$ content, and in $\mathbf{e}$ to elevated $\mathrm{F}$ concentrations

Fig. 9 Characteristics of calcrete and Microcodium aggregates from the ČOK section. a-c Field exposure and polished slab of calcrete representing a regional subaerial unconformity within marine limestones of the Ciovo Formation. a Reddish and brownish calcrete present as irregular patches within white marine limestones of the Ciovo Formation. Hammer is $32 \mathrm{~cm}$ long. b Polished slab with in situ Microcodium aggregates and calcrete in sharp contact (black arrows) with white marine limestone. $\mathbf{c}$ Fresh surface of calcrete showing its nodular structure, with larger nodules indicated by white arrows. d Thin-section showing nodular $(n)$ structure of calcrete in sharp contact with white limestone. e Photomicrographs of calcrete with nodular structure. Nodules $(n)$ are separated by irregular sparite-filled cavities surrounded by dark grey micrite. Some cavities are partly filled with multiple layers of brownish isodiametric and elongated calcite crystals interpreted as multilayered calcified root cells and/or Microcodium type $\mathrm{b}$ aggregates (white arrows), indicating location of the former root $(r z)$. f Photomicrograph of spar-filled cavities with well-developed alveolar-septal structure growing into pore space (black arrows) and possibly lining cavity walls (root tubules) (white arrows). $\mathbf{g}, \mathbf{h}$ Microphotographs showing several typical morphotypes of Microcodium composed of single layers of elongated calcite prisms, including cylindrical (c), spheroidal (s) and laminar (black and white arrow in $\mathbf{h}$ ), as well as multiple layers of brownish isodiametric and slightly elongated calcite crystals with planar crystal boundaries $(c c)$, resembling multilayered calcified root cells 

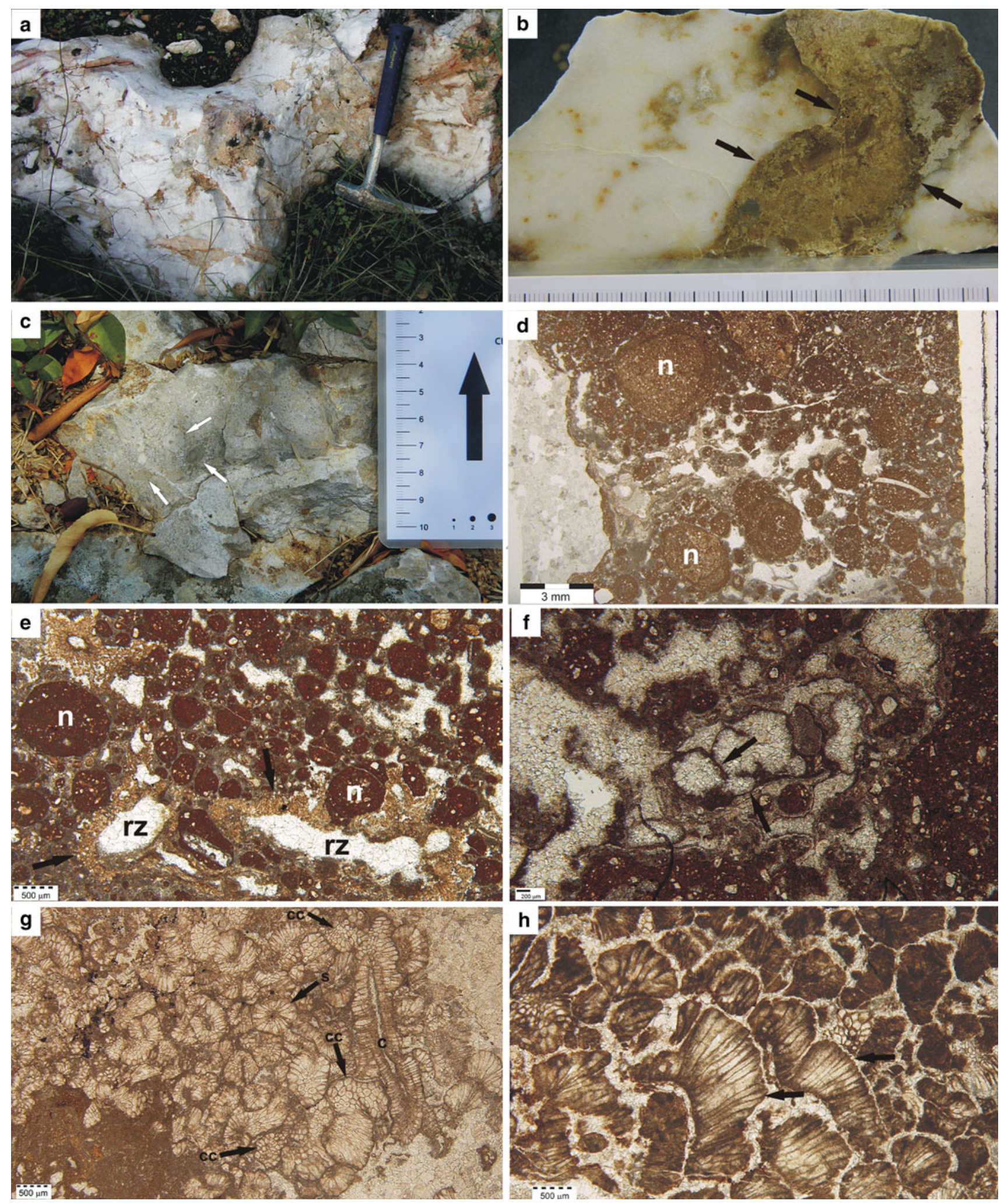

\section{Chemostratigraphy}

The mean ${ }^{87} \mathrm{Sr} /{ }^{86} \mathrm{Sr}$ value of three rudist bioclast samples from facies unit 2 of the Dol Formation is
$0.707551 \pm 6 \times 10^{-6}$ ( 2 s.e. $)$, and the derived numerical age is $78.8 \pm 0.6 \mathrm{Ma}$ (using the table of McArthur et al. 2001), which is within the range of the Middle Campanian substage according to Gradstein et al. (1994). Details 
concerning strontium isotope stratigraphy can be found in Steuber et al. (2005).

A detailed meter-scale carbon isotope stratigraphy on 170 samples from the Čiovo succession was undertaken, but the inter-sample variations were greater than the documented magnitude of global variations in carbon-isotope values of Upper Cretaceous marine carbonate deposits (e.g., Jarvis et al. 2002). Therefore, the results were not useful for chemostratigraphic analysis and are not presented here.

\section{Discussion}

Age determination

Association of planktonic foraminifera (Fig. 10) and strontium isotope stratigraphy suggest a Middle $(78.8 \pm 0.6 \mathrm{Ma}$ based on SIS) to Late Campanian age (stratigraphic range from at least the Late Campanian $R$. calcarata through the Early Maastrichtian G. gansseri planktonic foraminiferal zones) for the Dol Formation. The association of planktonic foraminifera from the Čiovo Formation indicates a stratigraphic range from at least the Late Campanian $R$. calcarata through the Late Maastrichtian A. mayaroensis planktonic foraminiferal zones, which is in agreement with the stratigraphic range of benthic foraminifera $S$. calcitrapoides recorded in the Čiovo Formation. However, according to Hottinger and Caus (2007), V. catalana, which was recorded in the upper part of the Čiovo Formation, spans through the Latest Campanian (i.e., G. gansseri or R. calcarata planktonic foraminiferal zone). Therefore, the stratigraphic age suggested here for the Čiovo Formation is Late Campanian (from at least the Late Campanian $R$. calcarata planktonic foraminifer zone).

The associations of planktonic and benthic foraminifera present in the Čiovo Formation have not been previously recorded from Upper Campanian carbonate successions of the ADCP. In addition, this study documents for the first time the presence of $V$. catalana in the southern Tethyan bioprovince. The present level of biostratigraphic resolution, however, does not allow us to determine if the succession examined on Čiovo is chronostratigraphically continuous. The biostratigraphic record (benthic foraminifera) of Upper Cretaceous neritic environments generally has a rather low frequency $\left(10^{6}-10^{7}\right.$ years $)$ resolution (Borgomano 2000) and the planktonic foraminifera documented on Čiovo determine stratigraphic range rather than individual planktonic foraminiferal zones. Similarly, the amount of time represented by the firmground surfaces in the Čiovo succession cannot be constrained (see also discussion on lateral differences in the firmground development within the Čiovo Formation).
Depositional settings, discontinuity surfaces, and local stratigraphic correlation

\section{Depositional settings}

Although not completely exposed, detailed geological mapping revealed that the Dol Formation is over $100 \mathrm{~m}$ thick on Čiovo (Fig. 1d). This formation is named after the previously established lithostratigraphic unit composed of Coniacian to Campanian basinal limestones on the Croatian Island of Brač (Gušić and Jelaska 1990; Steuber et al. 2005). The Dol Formation forms the basal $56 \mathrm{~m}$ of the ČOK section, which is mainly represented by typical pelagic limestone in the form of wackestone-packstone with planktonic microfossils (calcispheres and planktonic foraminifera) (facies type 1) and chert nodules (Table 1; Figs. 3, 4). Bioclastic-lithoclastic carbonates recorded in the ČOK section (facies type 2) and laterally in the southern part of the island (facies type $2_{1}$ ) as intercalations within pelagic wackestone-packstone in the Dol Formation (Table 1; Figs. 1d, 3, 4), are interpreted here as calciturbidites. Their characteristic sedimentary structures (only locally with debrite characteristics), texture, background sedimentation, and resedimented lithoclasts composed of wackestone-packstone with pelagic microfossils (calcispheres, planktonic foraminifera), all indicate a deeperwater, slope or basin setting (Flügel 2004; Rubert et al. 2012). These characteristics also exclude the possibility of misinterpretation as shallower-water tempestites or contour current deposits (Flügel 2004; Rubert et al. 2012). Normally graded, basal bioclastic-lithoclastic units of these turbidites could be tentatively described as Division A of the Bouma sequence, and as Zone $1 \mathrm{a}$ and $1 \mathrm{~b}$ of the Meischner sequence. Parallel lamination, from the upper parts of the turbiditic beds (facies type $2_{1}$ ), could correspond to Division B and Zone 1c of the Bouma and Meischner sequences, respectively.

The basal and upper parts of gravity-flow beds (facies type $2_{2}$ ) (Table 1; Fig. 4) are characterized by sedimentary structures (sharp lower boundary, normal grading, parallel lamination in the upper part, gradual transition into overlying pelagic wackestone to packstone) identical to turbidites (facies type $2_{1}$ ) (although much thinner). However, the central parts of these beds show significant vertical breaks in the dominant grain-size and facies type, which is commonly recorded in proximal turbidites (Flügel 2004). Therefore, these beds may represent amalgamated beds with internal erosion surfaces that form during early stages of turbiditic flow with surging (Tucker and Wright 1990). Alternatively, the lower and central parts of these beds might represent some form of debris-flow deposit (without grading and with large decimeter-sized lithoclasts of pelagic limestones), that transition upward into turbidites. 

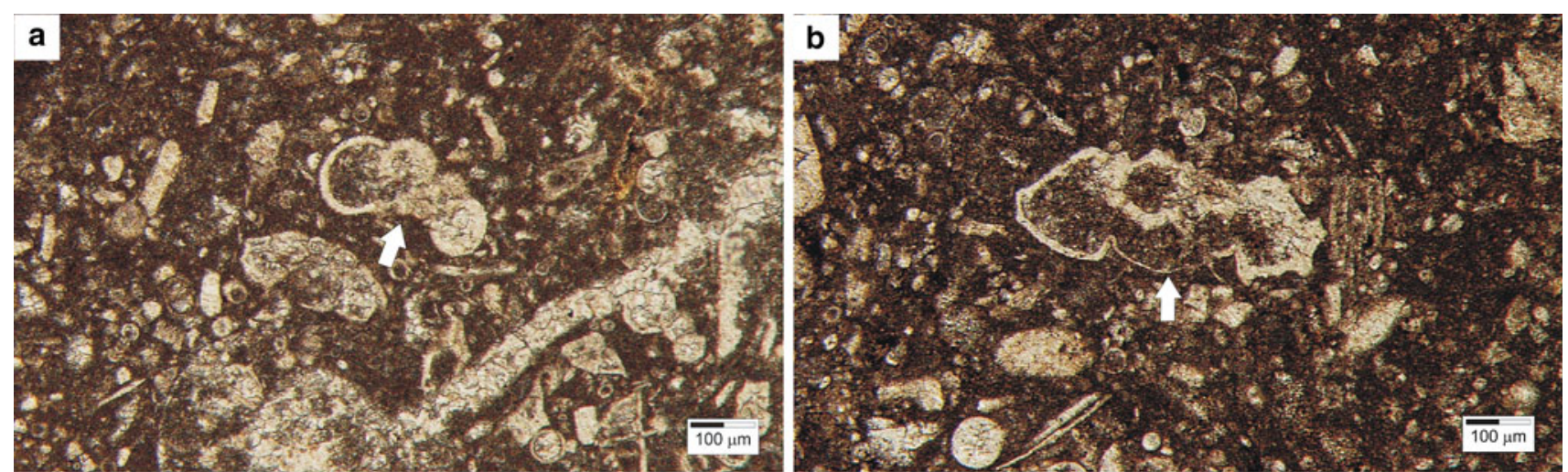

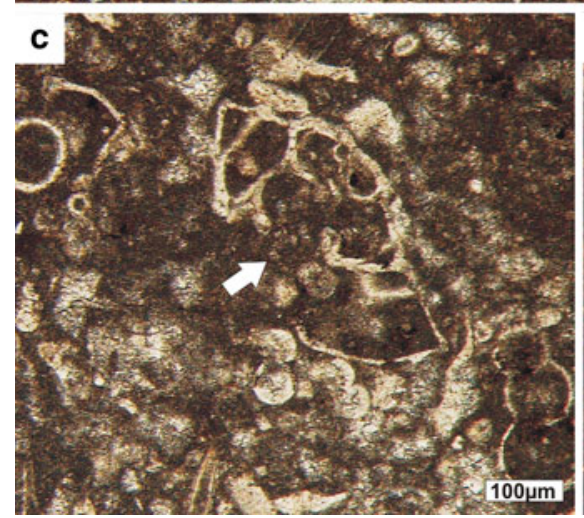

Fig. 10 Planktonic foraminifera (arrows) of the Dol (a, b) and Čiovo (c-e) Fms. a M. monmouthensis Olsson, axial section. b $R$. subcircumnodifer Gandolfi, (sub)axial section. c Globotruncanita stuarti de
Lapparent, axial section. d G.cf. stuarti de Lapparent, axial section. e Globotruncana cf. rosetta (Carsey), axial section
Possible triggers (e.g., tectonics and eustatic sea-level fluctuations) for gravity-flow deposition have been thoroughly discussed previously (e.g. Tucker et al. 1993; Betzler et al. 1999), including specifically the Upper Cretaceous turbiditic and debritic deposits of the periAdriatic region (Rubert et al. 2012 and references therein).

Pelagic limestones with intercalations of turbiditic and debritic deposits are commonly found in toe-of-slope to slope or basinal environments (Tucker and Wright 1990; Borgomano 2000; Flügel 2004). However, they are also common constituents of the outer part of distally steepened ramps (i.e., ramps with a slope break in deep-water) (Mutti et al. 1996; Betzler et al. 1999; Flügel 2004). The present data do not allow an unequivocal distinction between these two settings proposed for the deposition of the Dol Formation. However, the term slope setting is used for simplicity.

The Čiovo Formation (Table 1; Fig. 5), on the other hand, is interpreted as outer ramp deposits. Lithoclasts of pelagic wackestone to packstone present within the bioclastic-lithoclastic packstone indicate a deeper-water and open-marine outer ramp below storm wave base. In addition, deposits characteristic of middle (e.g., tempestites) or inner ramp, as well as distally steepened ramp or slope (e.g., gravity-flow deposits) (Wright 1986; Tucker and Wright 1990; Flügel 2004) were not recorded. The orbitoidid and siderolitine hyaline benthic foraminifera of the Čiovo Formation (Fig. 11) may also serve as bathymetric indicators. Depending on seawater transparency, these foraminifera occur from about 40 to $130 \mathrm{~m}$ water depth (Cvetko Tešović et al. 2001 and references therein). Echinoderm limestone interbedded with bioclastic-lithoclastic packstone strata of the Čiovo Formation (Fig. 3), is also interpreted as being deposited on the outer ramp. Although such deposits may form in various depositional settings (see review in Flügel 2004), on Čiovo they contain no structures and textures indicative of a middle ramp (e.g., storm influence and allochthonous tempestitic origin; Flügel 2004), inner ramp (e.g., Wright 1986), or slope and basinal settings with allochthonous turbiditic echinoderm accumulations (Tucker 1969).

Lithology, facies and depositional settings of the Upper Campanian Čiovo Formation differ from the penecontemporaneous and regionally important Upper Campanian to Maastrichtian (?Paleocene) Sumartin Formation on the Island of Brač in Croatia, deposited in an inner-platform setting (Gušić and Jelaska 1990; Cvetko Tešović et al. 2001; Steuber et al. 2005), and from the Paleocene Tilovica 
succession, composed of calcidebrites with intercalations of limestones with planktonic foraminifera, deposited within a basin (i.e., NEAT sensu Korbar 2009) by submarine debris flows. Calcidebrites with pelagic intercalations, according to Ćosović et al. (2006), extend chronostratigraphically into the "Late Senonian" (possibly Late Campanian to Maastrichtian). The Čiovo Formation is therefore established here as a new lithostratigraphic unit, especially important for regional geological mapping (e.g., the new Basic Geological Map of the Republic of Croatia 1:50.000).

The interpretations of depositional environments imply shallowing of the slope setting of the Middle to Upper Campanian Dol Formation to an outer ramp for the Upper Campanian Čiovo Formation. Sequence stratigraphy of carbonate ramps and the responses of carbonate ramps to relative fall in sea-level have been discussed by numerous authors (e.g., Hunt and Tucker 1992; Tucker et al. 1993; Mutti et al. 1996; Rankey 2003).

\section{Firmgrounds}

Firmgrounds are grouped into the condensation surface category of discontinuity surfaces (Hillgärtner 1998), and are considered as stiff but unlithified substrates (Tucker
2011). Burrowing structures associated with the lower (FG-1) and upper firmgrounds (FG-2) from the Čiovo succession (Figs. 6,7) are assigned to the Thalassinoides ichnogenus (probably Thalassinoides paradoxicus) (for a review see Rodríguez-Tovar et al. 2008 and references therein). The sharp unlined walls, passive fill and vertical to subvertical domichnia are typical features and clearly indicate that these burrows belong to the Glossifungites ichnofacies (Bromley 1975; Pemberton et al. 2004; Schwarz and Buatois 2012). In addition, burrows of the upper firmground are filled with sediment that was not observed in the overlying strata and which might indicate recurrent phases of deposition and erosion (Hillgärtner 1998). Association of phosphatic mineralization with Thalassinoides trace fossils (Figs. 6, 7, 8) represents additional support for the discontinuous nature of these stratigraphic horizons (see Chacón and Martín-Chivelet 2008 and references therein). The lower (FG-1) and upper (FG-2) firmgrounds extend for $>3 \mathrm{~km}$ laterally from the ČOK section (Fig. 1d), which indicates that these surfaces are at least regionally important (Di Stefano et al. 2002; Flügel 2004; Christ et al. 2012; Schwarz and Buatois 2012).

Lateral differences in firmground development within the Čiovo Formation, such as the firmground(s) recorded above FG-2 (Fig. 7) which is not recorded in the ČOK
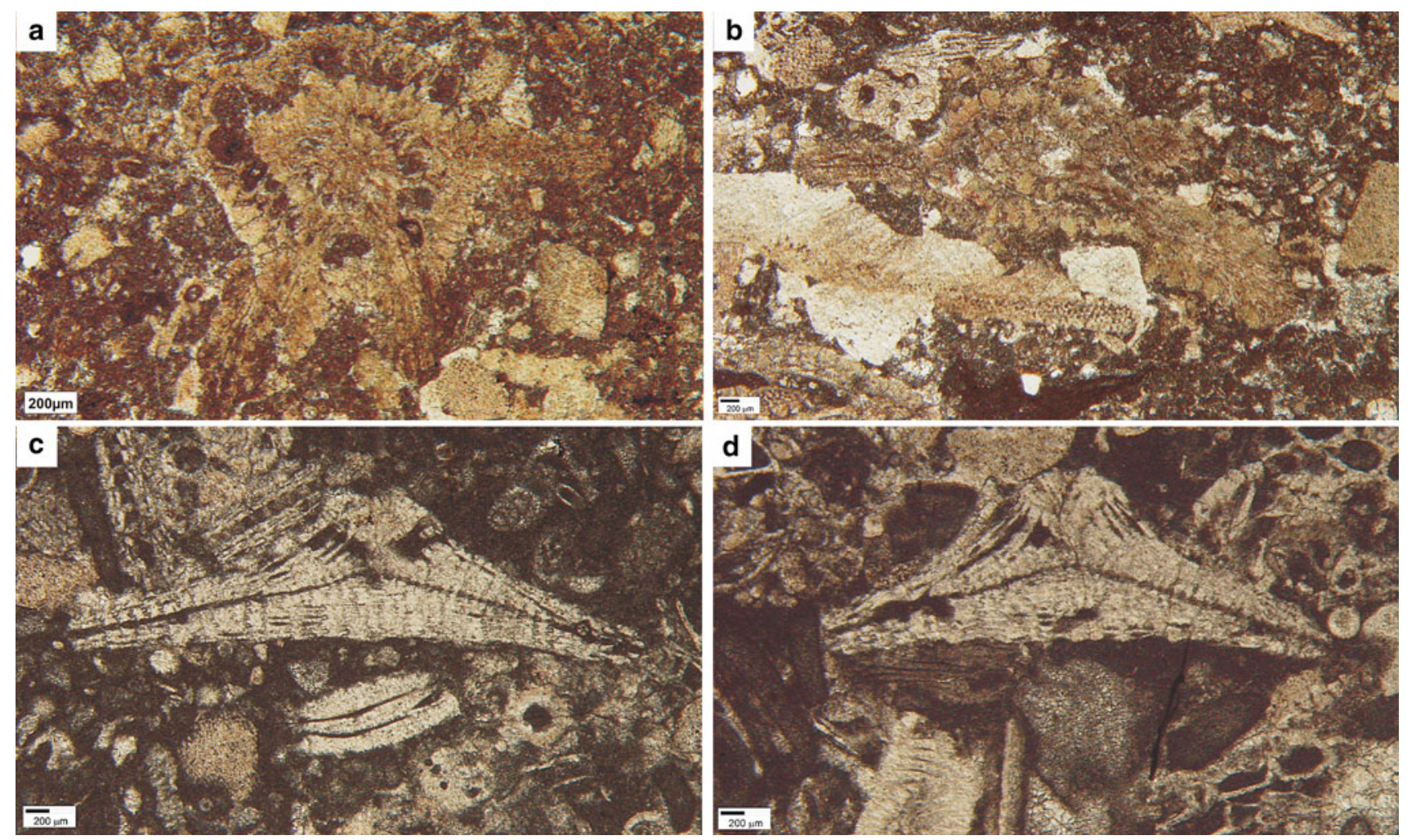

Fig. 11 Late Campanian larger benthic foraminifera of the Čiovo Formation. a, b S. calcitrapoides Lamarck, oblique sections. c, d V. catalana Hottinger and Caus, axial sections 
section, may indicate laterally different local or regional depositional conditions (e.g., different rates of sedimentation). Since firmgrounds mark hiatuses, periods of nondeposition and deposition represented by firmgrounds and sedimentary strata, respectively, may have different duration laterally. The Čiovo Formation may be laterally variable and the possible local or regional importance as well as model for formation (e.g., Christ et al. 2012) of this additional firmground(s) (above FG-2) is yet to be established.

\section{Subaerial exposure surface}

Calcrete and Microcodium aggregates are defined as markers of subaerial exposure surfaces (Hillgärtner 1998). The calcrete features such as the ones recorded from Čiovo have been well documented (e.g., Košir 2004; AlonsoZarza and Wright 2010 and references therein).

Lateral extent of the subaerial exposure surface with calcretes on Čiovo is greater than $3 \mathrm{~km}$ and indicates its at least regional importance (Flügel 2004). Although in general calcretes may be much younger than the strata within which they develop (Rossinsky et al. 1993), calcretes from Ćiovo are interpreted as older than the transgressive marine Eocene Foraminiferal limestones, which unconformably overlie the Upper Cretaceous Čiovo succession and were deposited in ramp environments during progressive deepening (Ćosović et al. 2004, i.e., development of foreland basin) in response to the Dinaridic orogen (see Korbar 2009). Correlative subaerial exposure surfaces have also been recorded in other ADCP Upper Cretaceous successions (see below).

Regional Campanian stratigraphic framework and correlation

The Čiovo succession reflects shallowing from the Middle to Upper Campanian Dol Formation to the Upper Campanian Čiovo Formation. There were two main phases of sea-level change in Middle and Late Campanian, which appear to be synchronous in northern Europe (e.g., England and France), and North Africa (e.g., Egypt, NW and NE Tunisia), and imply the dominance of eustatic over regional tectonic forcing (Lüning et al. 1998; Jarvis et al. 2002; Bey et al. 2012). The Mid-Campanian Event (sensu Jarvis et al. 2002) was recorded within the Globotruncana ventricosa Zone (dated at $78.7 \mathrm{Ma}$ ) and represented transgression after a major sea-level fall (e.g., Lüning et al. 1998). The Upper Campanian Event (UCE) (sensu Jarvis et al. 2002) was recorded at the bottom of the $G$. gansseri Zone (above $R$. calcarata Zone) (dated at $74.8 \mathrm{Ma}$ ) and represented a major sea-level fall followed by transgression. The UCE was also tentatively interpreted to be recorded regionally at $77-75 \mathrm{Ma}$ (dated by strontium isotope stratigraphy and correlated to the biostratigraphic boundary between CsB5 and CsB6 biozone; Fig. 12), and manifested as a regionally important subaerial exposure surface on the Island of Brač (Gušić and Jelaska 1990; Steuber et al. 2005), the Apulian carbonate platform in Italy (Schlüter et al. 2008), and the Kruja platform in Albania (Heba et al. 2009). In addition, the Late Campanian sea-level fall recorded in the Maiella platform margin in Italy (unconformity below the Orfento Formation; Eberli et al. 1993; Mutti et al. 1996), might also represent the UCE of Jarvis et al. (2002) (Fig. 12) or be of a more regional occurrence. Several other Late Campanian to Early Maastrichtian major eustatic sea-level falls have also been documented (Steuber and Schlüter 2012 and references therein).

The UCE of Jarvis et al. (2002) (Fig. 12), which represents an eustatic sea-level fall recorded globally and regionally, is the most likely cause for the observed changes in depositional environments and formation of regionally important condensation surfaces in the Čiovo succession. The lower firmground (FG-1) which marks the boundary between the Dol and Čiovo Fms (Fig. 3), was likely formed due to regression (lowstand) (see Gomez and Fernandez-Lopez 1994; Clari et al. 1995; Christ et al. 2012; Schwarz and Buatois 2012), while the upper firmground (FG-2) might represent a period of subsequent maximum transgression (maximum flooding surface; see Hillgärtner 1998), as generally indicated by the sedimentological evidence in the succession (fining-upward trend from FG-1 to FG-2). Consequently, part of the Čiovo Formation above the upper firmground could represent high-stand systems tract deposits. Possible correlation of the lower firmground (FG-1) from the Čiovo succession with the regionally recorded UCE on the Island of Brač and Apulia (Fig. 12) would indicate lateral transition in the type of discontinuity surfaces from a subaerial exposure surface on platform tops to a submarine condensed surface in slope settings. Accordingly, the UCE can be correlated regionally within the central-southern Tethyan platforms, shelves, and their margins (Fig. 12). However, due to the uncertainties in correlation of SIS and biostratigraphy (see discussion in Jarvis et al. 2002; Wagreich et al. 2012; Steuber and Schlüter 2012), and limitations of the currently available biostratigraphic, mineralogical and chemostratigraphic data from the Čiovo succession, we cannot unequivocally correlate our findings to any specific or several particular global and regional Middle to Upper Campanian eustatic sea-level change events (Jarvis et al. 2002; Steuber et al. 2005; Steuber and Schlüter 2012 and references therein). In addition, other processes besides (or in combination with) eustatic sea-level change may have caused the described facies changes, non-deposition, and formation of 


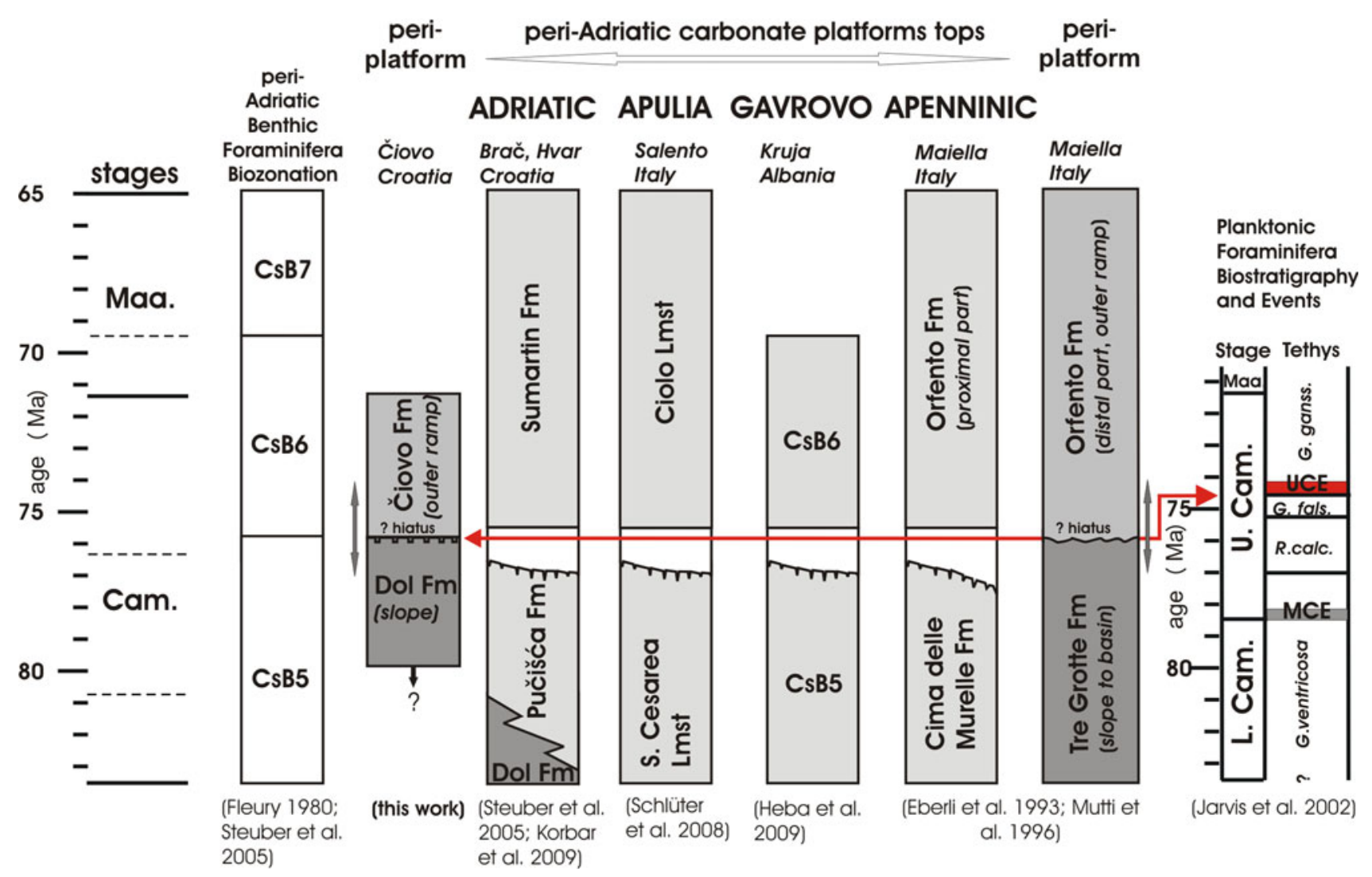

Fig. 12 Regional (peri-Adriatic, see also Fig. 1a) correlation of Campanian to Maastrichtian platform and peri-platform successions, with emphasis on the key formational boundaries, that are presumably related to proposed synchroneity of the UCE sensu Jarvis et al. (2002). Grey arrows indicate uncertainties on the boundaries within Ćiovo and Maiella peri-platform successions. Red line indicates discrepancy in age correlation of globally recorded UCE with the discussed platform-top sequence boundaries, which could be the result of problems in global correlation of chrono-, chemo-, and

condensed surfaces in the Čiovo succession (e.g., regional tectonics, see Di Stefano and Mindszenty 2000; Borgomano 2000; Sar1 2009; Schwarz and Buatois 2012). Resolving these uncertainties will be the focus of our future investigations.

ADCP paleogeography and tectonostratigraphic affinities

According to Korbar (2009), a slope existed on the southern part of the Dinaridic segment during the Late Cretaceous, facing the NE Adriatic trough from the north (Fig. 1a), and today this is in a highly allochthonous position. The interpretation includes a hypothetically continuous trough that separated the Dinaridic and Adriatic segments during the Late Cretaceous (question marks and dotted line separating the Dinaridic and Adriatic platforms on Fig. 1a). According to the model, the Veli Rat Formation, which is part of a more than 800 -m-thick succession biostratigraphy, which together with uncertainties on the age of the key formational boundary on peri-platform slopes and basins, leaves out unequivocal conclusions. Time scales on the left are from Obradovich (1993; 70-98.5 Ma) and Cande and Kent (1995; 70-65 Ma); Campanian and Maastrichtian substage boundaries (dashed lines) are after Gradstein et al. (1994). Time scale on the right is from Gradstein et al. (1995). Note that biostratigraphic zonation based on planktonic foraminifera presented by Jarvis et al. (2002) differs somewhat from that of Premoli Silva and Verga (2004)

originally described on the Dugi Otok Island (located $150 \mathrm{~km} \mathrm{NW}$ of Čiovo, close to the front of the External Dinarides; Figs. 1b, 2) (Kapović and Bauer 1971), consists of slope to basin carbonates presumably deposited on the southern margin of the Dinaridic segment of the ADCP domain. This could also be the case for the Čiovo area. In contrast, the Dol Formation is intercalated within the Upper Cretaceous peritidal strata as a unit typical of the Adriatic segment of the ADCP. Unfortunately, the present data do not permit definite placement of calcisphere limestone with turbidites and/or debrites from Čiovo Island within the Veli Rat Formation or the Dol Formation. The only clear difference between these two deeper-water units is their stratigraphic range, but unfortunately the critical data are missing because the deposits which underlie the slope succession on Čiovo are not exposed (Fig. 1d).

The succession on Čiovo could have also been deposited on the northernmost part of the Adriatic segment of the ADCP, characterized by slope-to-ramp facies during the 
Middle to Late Campanian, and facing the NE Adriatic trough from the south. However, the Čiovo succession lacks at least 200-m-thick Maastrichtian inner-platform succession, which was deposited within the platform-top succession on Brač Island. Therefore, the slope environment evidenced by turbidite and debrite beds, referred to tentatively here as the Dol Formation, could instead be a proximal equivalent of the Veli Rat Formation (Kapović and Bauer 1971). If so, paleogeographically the Island of Čiovo could be more appropriately placed on the southern margin of the Dinaridic segment, which overthrusted the Adriatic segment during the Paleogene orogenesis. However, the definite paleogeographic position of the Čiovo succession cannot yet be determined with certainty.

The subaerial exposure surface from the uppermost part of the Čiovo Formation, which is represented by calcrete and Microcodium aggregates, has also been recorded in other ADCP Upper Cretaceous successions of different stratigraphic age (from Cenomanian to Maastrichtian), which are unconformably overlain by transgressive marine Paleogene deposits (Steuber et al. 2005; Vlahović et al. 2005; Korbar 2009). Hiatuses along these surfaces are on the order of several My in duration and are commonly marked by well-developed paleokarstic horizons and bauxitic deposits (Otoničar 2007; Kovačević Galović et al. 2012), which reflect significant environmental changes in response to global, long-term processes of tectono-eustatic origin (Clari et al. 1995; D’Argenio and Mindszenty 1995; Hillgärtner 1998). The regional Late Cretaceous to Paleogene emergence phase of variable duration on different parts of the ADCP was caused by very intensive Late Cretaceous syn-sedimentary tectonics related to the collision of Adria with the Euroasian plate (Vlahović et al. 2005; Korbar 2009). The Cretaceous to Paleogene hiatus is interpreted as a consequence of diachronous and differential uplifts of various parts of the platform(s) in response to diachronous forebulging in front of the approaching Dinaridic orogen (Otoničar 2007; Korbar 2009). However, this hiatus is also recorded elsewhere in the Adriatic region (Bosellini et al. 1999), and thus cannot be related to the forebulge effect only.

Nevertheless, these various possibilities indicate differentiated depositional settings in the ADCP domain during the Upper Cretaceous to Paleogene (see Vlahović et al. 2005; Ćosović et al. 2006; Korbar 2009). The new stratigraphic interpretations of the succession analyzed here form a basis for future comparisons and correlations that will provide a better understanding of the complex depositional, tectonostratigraphic and paleogeographic setting of the region during the Late Cretaceous and Paleocene times.

\section{Conclusions}

1. The examined carbonate succession from the Island of Čiovo (central Dalmatia, Croatia) consists of two lithostratigraphic units: the underlying Middle to Upper Campanian Dol Formation slope deposits, and the overlying Upper Campanian outer ramp deposits of the Čiovo Formation. The Čiovo Formation is proposed here as a new lithostratigraphic unit that differs substantially from the penecontemporaneous typical inner-platform ADCP deposits common elsewhere in the region (e.g., Sumartin Formation on Brač Island).

2. The two discontinuity surfaces present in the lower part of the Čiovo succession were classified as firmgrounds based on the presence of Thalassinoides burrows that belong to the Glossifungites ichnofacies. Lateral extent of the two firmgrounds (more than $3 \mathrm{~km}$ ) indicates their at least regional importance.

3. Abrupt shallowing of depositional environments at the boundary of the Dol and the Čiovo Fms, together with development of the formational boundary firmground (FG-1), likely correlate with the regionally recorded UCE that represents a global eustatic fall in sea-level.

4. The subaerial exposure surface from the uppermost part of the Čiovo Formation, which is represented by calcrete and Microcodium aggregates, corresponds to the regionally important Cretaceous to Paleogene $(\mathrm{K}-\mathrm{Pg})$ subaerial unconformity recorded elsewhere within the Upper Cretaceous ADCP carbonate successions. The emergence is interpreted as the formation of a forebulge during the Late Cretaceous in front of the approaching Dinaridic orogen, which differentially affected various sectors of the carbonate platform.

Acknowledgments This study was supported by the project "Stratigraphy and Geodynamic Context of Cretaceous Deposits in the NE Adriatic Region" (No. 181-1191152-2697) of the Ministry of Science, Education and Sports of the Republic of Croatia. We would like to thank Facies Co-Editor Maurice Tucker for his very helpful comments, suggestions and editorial work that greatly improved the manuscript. Professor Sevinc Altiner and an anonymous reviewer are thanked for their useful comments, John Brady (Smith College) for his help with SEM/EDS analyses, Croatian Geological Survey Lab team for thin-section preparation, Ivo Suša for technical support, and Krešimir Markulin for field assistance.

\section{References}

Alonso-Zarza AM, Wright VP (2010) Calcretes. In: Alonso-Zarza AM, Tanner LH (eds) Carbonates in continental settings: facies, environments and processes. Developments in sedimentology 61:225-269

Alonso-Zarza AM, Sanz ME, Calvo JP, Estévez P (1998) Calcified root cells in Miocene pedogenic carbonates of the Madrid Basin: 
evidence for the origin of Microcodium b. Sediment Geol 116:81-97

Betzler C, Reijmer JJG, Bernet K, Eberli GP, Anselmetti FS (1999) Sedimentary patterns and geometries of the Bahamian outer carbonate ramp (Miocene-Lower Pliocene, Great Bahama Bank). Sedimentology 46:1127-1143

Bey S, Kuss J, Premoli Silva I, Negra MH, Gardin S (2012) Faultcontrolled stratigraphy of the Late Cretaceous Abioid Formation at Ain Medheker (Northeast Tunisia). Cretac Res 34:10-25

Borgomano JRF (2000) The Upper Cretaceous carbonates of the Gargano-Murge region (southern Italy): a model of platform-tobasin transition. AAPG Bull 84:1561-1588

Bosellini A, Morsilli M, Neri C (1999) Long-term event stratigraphy of the Apulia platform margin (Upper Jurassic to Eocene, Gargano, southern Italy). J Sediment Res 69:1241-1252

Bromley RG (1975) Trace fossils at omission surfaces. In: Frey RW (ed) The study of trace fossils. Springer, Berlin, pp 399-428

Cande SC, Kent DV (1995) Revised calibration of the geomagnetic polarity time scale for the Late Cretaceous and Cenozoic. J Geophys Res 100:6093-6095

Caus E, Gómez-Garrido A (1989) Upper Cretaceous biostratigraphy of the south-central Pyrenees (Lleida, Spain). Geodin Acta 3:221-228

Chacón B, Martín-Chivelet J (2008) Stratigraphy of Paleocene phosphate pelagic stromatolites (Prebetic Zone, SE Spain). Facies 54:361-376

Christ N, Immenhauser A, Amour F, Mutti M, Tomas S, Agar SM, Alway R, Kabiri L (2012) Characterization and interpretation of discontinuity surfaces in a Jurassic ramp setting (High Atlas, Morocco). Sedimentology 59:249-290

Chrowicz J (1975) Le devenir de la zone de Budva vers le Nord-Ouest de la Yougoslavie. Bull Soc Geol Fr 7:699-709

Clari PA, Della Pierre F, Martire L (1995) Discontinuities in carbonate successions: identification, interpretation and classification of some Italian examples. Sediment Geol 100:97-121

Ćosović V, Drobne K, Moro A (2004) Paleoenvironmental model for Eocene foraminiferal limestones of the Adriatic carbonate platform (Istrian Peninsula). Facies 50:61-75

Ćosović V, Premec Fuček V, Gušić I, Jelaska V, Moro A (2006) The age of the Tilovica breccias in Central Dalmatia, Croatia. Micropaleontology 52:281-286

Cvetko Tešović B, Gušić I, Jelaska V, Bucković D (2001) Stratigraphy and microfacies of the Upper Cretaceous Pučišća Formation, Island of Brač, Croatia. Cretac Res 22:591-613

D'Argenio B, Mindszenty A (1995) Bauxites and related paleokarst: tectonic and climatic event markers at regional unconformities. Eclog Geolog Helvet 88:453-499

Di Stefano P, Mindszenty A (2000) Fe-Mn-encrusted "Kamenitza" and associated features in the Jurassic of Monte Kumeta (Sicily): subaerial and/or submarine dissolution? Sediment Geol 132:37-68

Di Stefano P, Galácz A, Mallarino G, Mindszenty A, Vörös A (2002) Birth and early evolution of a Jurassic escarpment: Monte Kumeta Western Sicily. Facies 46:273-298

Dunham RJ (1962) Classification of carbonate rocks according to depositional texture. AAPG Mem 1:108-121

Eberli GP, Bernoulli D, Sanders D, Vecsei A (1993) From aggradation to progradation: the Maiella platform (Abruzzi, Italy). In: Simo AJ, Scott R, Masse JP (eds) Cretaceous carbonate platforms. AAPG Mem 56:213-232

Embry AF, Klovan JE (1971) A late Devonian reef on northeastern Banks Island, NWT. Bull Can Petrol Geol 19:730-781

Fleury JJ (1980) Les zones de Gavrovo-Tripolitza et du Pinde-Olonos (Grèce continentale et Peloponnèse du Nord). Èvolution d'une plateforme et d'un bassin dans leur cadre alpin. Publ Soc Gèol Nord 4, p 651
Flügel E (2004) Microfacies of carbonate rocks, analysis, interpretation and application. Springer, Berlin, p 976

GKRH (2009) Geološka karta Republike Hrvatske (Geological Map of the Republic of Croatia) scale 1:300.000. Hrvatski geološki institut (Croatian Geological Survey, Zagreb), 1 sheet

Gomez JJ, Fernandez-Lopez S (1994) Condensation processes in shallow platforms. Sediment Geol 92:147-159

Gradstein FM, Agterberg FP, Ogg JG, Hardenbol J, van Veen P, Thierry J, Huang Z (1994) A Mesozoic time scale. J Geophys Res 99:24051-24074

Gradstein FM, Agterberg FP, Ogg JG, Hardenbol J, Van Veen P, Thierry J, Huang Z (1995) A Triassic, Jurassic and Cretaceous time scale. In: Bergrren WA, Kent DV, Aubry M-P, Hardenbol J (eds) Geochronology, time scales and global stratigraphic correlation. SEPM Spec Publ 54:95-126

Gušić I, Jelaska V (1990) Upper Cretaceous stratigraphy of the Island of Brač within the geodynamic evolution of the Adriatic carbonate platform. Djela Jugoslavenske akademije znanosti i umjetnosti 69:160

Hardenbol J, Thierry J, Farley MB, Jacquin T, de Graciansky PC, Vail PR (1998) Cretaceous biochronostratigraphy. In: de Graciansky PC, Hardenbol J, Jacquin T, Vail PR (eds) Mesozoic and Cenozoic sequence stratigraphy of European basins. SEPM Spec Publ 60, Chart 5

Heba G, Prichonnet G, El Albani A (2009) Meteoric diagenesis of Upper Cretaceous and Paleocene-Eocene shallow-water carbonates in the Kruja Platform (Albania): geochemical evidence. Geol Carpath 60:165-179

Hillgärtner H (1998) Discontinuity surfaces on a shallow-marine carbonate platform (Berriasian, Valanginian, France and Switzerland). J Sediment Res 68:1093-1108

Hottinger L, Caus E (2007) Shell architecture in the Late Cretaceous foraminiferal subfamily Clypeorbinae Sigal, 1952. J Foraminiferal Res 37:372-392

Hunt D, Tucker ME (1992) Stranded parasequences and the forced regressive wedge systems tract: deposition during base-level fall. Sediment Geol 81:1-9

Jarvis I, Mabrouk A, Moody RTJ, de Cabrera S (2002) Late Cretaceous (Campanian) carbon isotope events, sea-level change and correlation of the Tethyan and Boreal realms. Palaeogeogr Palaeoclimatol Palaeoecol 188:215-248

Jenkyns HC (1991) Impact of Cretaceous sea-level rise and anoxic events on the Mesozoic carbonate platform of Yugoslavia. AAPG Bull 75:1007-1017

Kapović B, Bauer V (1971) Sedimentološke, biofacijelne i ambijentalne karakteristike gornjokrednih naslaga otoka Premuda i Dugog otoka (Sedimentary, biofacies and environmental characteristics of Upper Cretaceous strata from the Islands of Premuda and Dugi otok, Croatia). Nafta 12:561-572

Korbar T (2009) Orogenic evolution of the External Dinarides in the NE Adriatic region; a model constrained by tectonostratigraphy of Upper Cretaceous to Paleogene carbonates. Earth Sci Rev 96:296-312

Korbar T, Cvetko Tešović B, Radovanović I, Krizmanić K, Steuber T, Skelton PW (2010) Campanian Pseudosabinia from the Pučišća Formation on the Island of Hvar (Adriatic Sea, Croatia). Turk J Earth Sci 19:721-731

Košir A (2004) Microcodium revisited: root calcification products of terrestrial plants on carbonate-rich substrates. J Sediment Res 74:845-857

Kovačević Galović E, Ilijanić N, Peh Z, Miko S, Hasan O (2012) Geochemical discrimination of Early Palaeogene bauxites in Croatia. Geol Croat 65:53-65

Lüning S, Marzouk AM, Morsi AM, Kuss J (1998) Sequence stratigraphy of the Upper Cretaceous of central-east Sinai, Egypt. Cretac Res 19:153-196 
Marjanac T, Babac D, Benić J, Ćosović V, Drobne K, Marjanac Lj, Pavlovec R, Velimirović Z (1998) Eocene carbonate sediments and sea-level changes on the SE part of Adriatic Carbonate Platform (Island of Hvar and Pelješac Peninsula, Croatia). In: Hottinger L, Drobne K (eds) Paleogene shallow benthos of the Tethys. Dela, Slovenska akademija znanosti in umetnosti (SAZU) 34:243-254

McArthur JM, Howarth RJ, Bailey TR (2001) Strontium isotope stratigraphy: lowess version 3. Best-fit to the marine Sr-isotope curve for 0 to $509 \mathrm{Ma}$ and accompanying look-up table for deriving numerical age. J Geol 109:155-170

Moro A, Skelton PW, Ćosović V (2002) Palaeonvironmental setting of rudists in the Upper Cretaceous (Turonian-Maastrichtian) Adriatic Carbonate Platform (Croatia), based on sequence stratigraphy. Cretac Res 23:489-508

Mutti M, Bernoulli D, Eberli GP, Vecsei A (1996) Depositional geometries and facies associations in an Upper Cretaceous prograding carbonate platform margin (Orfento Supersequence, Maiella, Italy). J Sediment Res 66:749-765

Obradovich JD (1993) A Cretaceous time scale. In: Caldwell WG, Kauffman EG (eds) Evolution of the Western Interior Basin. Geol Assoc Can Spec Pap 39:379-396

Otoničar B (2007) Upper Cretaceous to Paleogene forbulge unconformity associated with foreland basin evolution (Kras, Matarsko podolje and Istria; SW Slovenia and NW Croatia). Acta Carsologica 36:101-120

Özkan-Altiner S, Özcan E (1999) Upper Cretaceous planktonic foraminiferal biostratigraphy from NW Turkey: calibration of the stratigraphic ranges of larger benthonic foraminifera. Geol $\mathrm{J}$ 34:287-301

Pamić J, Gušić I, Jelaska V (1998) Geodynamic evolution of Central Dinarides. Tectonophysics 297:273-307

Pemberton SG, MacEachern JA, Saunders T (2004) Stratigraphic applications of substrate-specific ichnofacies: delineating discontinuities in the rock record. In: Mcllroy D (ed) The application of ichnology to palaeoenvironmental and stratigraphic analysis. Spec Publ Geol Soc Lond 228:29-62

Premoli Silva I, Verga D (2004) Practical manual of Cretaceous planktonic foraminifera. In: Verga D, Retorri R (eds) International school on planktonic foraminifera, $3^{\circ}$ course: Cretaceous. Universities of Perugia and Milan, Tipografia Pontefelcino, Perugia, p 299

Rameil N, Immenhauser A, Csoma AÉ, Warrlich G (2012) Surfaces with a long history: the Aptian top Shu'aiba Formation unconformity, Sultanate of Oman. Sedimentology 59:212-248

Rankey EC (2003) Carbonate-filled channel complexes on carbonate ramps: an example from the Peerless Park Member [Keokuk Limestone, Visean, Lower Carboniferous (Mississippian)], St. Louis, MO, USA. Sediment Geol 155:45-61

Rodríguez-Tovar FJ, Puga-Bernabéu Á, Buatois LA (2008) Large burrow systems in marine Miocene deposits of the Betic Cordillera (Southeast Spain). Palaeogeogr Palaeoclimatol Palaeoecol 268:19-25

Rossinsky V, Wanless HR, Swart PK (1993) Penetrative calcretes and their stratigraphic significance. Geology 20:331-334

Rubert Y, Jati M, Loisy C, Cerepi A, Foto G, Muska K (2012) Sedimentology of resedimented carbonates: facies and geometrical characterisation of an upper Cretaceous calciturbidite system in Albania. Sediment Geol 257-260:63-77

Sar1 B (2009) Planktonic foraminiferal biostratigraphy of the Coniacian-Maastrichtian sequences of the Bey Dağları Autochton, western Taurides, Turkey: thin-section zonation. Cretac Res 30:1103-1132

Sattler U, Immenhauser A, Hillgärtner H, Esteban M (2005) Characterization, lateral variability and lateral extent of discontinuity surfaces on a carbonate platform (Barremian to Lower Aptian, Oman). Sedimentology 52:339-361

Schlüter M, Steuber T, Parente M (2008) Chronostratigraphy of Campanian-Maastrichtian platform carbonates and rudist associations of Salento (Apulia, Italy). Cretac Res 29:100-114

Schwarz E, Buatois LA (2012) Substrate-controlled ichnofacies along a marine sequence boundary: the Intra-Valanginian Discontinuity in central Neuquén Basin (Argentina). Sediment Geol 277-278:72-87

Steuber T, Schlüter M (2012) Strontium-isotope stratigraphy of Upper Cretaceous rudist bivalves: biozones, evolutionary patterns and sea-level change calibrated to numerical ages. Earth Sci Rev 114:42-60

Steuber T, Korbar T, Jelaska V, Gušić I (2005) Strontium-isotope stratigraphy of Upper Cretaceous platform carbonates of the Island of Brač (Adriatic Sea, Croatia): implications for global correlation of platform evolution and biostratigraphy. Cretac Res 26:741-756

Tucker ME (1969) Crinoidal turbidites from the Devonian of Cornwall and their palaeogeographic significance. Sedimentology 13:281-290

Tucker ME (2011) Sedimentary rocks in the field: a practical guide, 4th edn. Wiley, West Sussex, p 288

Tucker ME, Wright VP (1990) Carbonate sedimentology. Blackwell Science Publications, Oxford, p 482

Tucker ME, Calvet F, Hunt D (1993) Sequence stratigraphy of carbonate ramps: system tracts, models and application to the Muschelkalk carbonate platforms of eastern Spain. Int Ass Sediment Spec Publ 18:397-415

Vicedo V, Frijia G, Parente M, Caus E (2011) The Late Cretaceous genera Cuvillierinella, and Rhapydionina (Rhapydioninidae, foraminiferida) in shallow-water carbonates of Pillos (Peloponnese, Greece). J Foraminiferal Res 41:167-181

Vlahović I, Tišljar J, Velić I, Matičec D (2005) Evolution of the Adriatic Carbonate Platform: palaeogeography, main events and depositional dynamics. Palaeogeogr Palaeoclimatol Palaeoecol 220:333-360

Wagreich M, Hohenegger J, Neuhuber S (2012) Nannofossil biostratigraphy, strontium and carbon isotope stratigraphy, cyclostratigraphy and an astronomically calibrated duration of the Late Campanian Radotruncana calcarata Zone. Cretac Res. doi: 10.1016/j.cretres.2012.04.006

Wright VP (1986) Facies sequences on a carbonate ramp: the Carboniferous Limestone of South Wales. Sedimentology 33:221-241

Wright VP (1994) Paleosols in shallow marine carbonate sequences. Earth Sci Rev 35:367-395 